\title{
The Balkan Psorodonotus (Orthoptera: Tettigoniidae): Testing the existing taxa confirmed presence of three distinct species
}

\author{
Sarp KAYA ${ }^{1}$, Dragan P. CHOBANOV ${ }^{2, *}$, Josip SKEJO ${ }^{3}$, Klaus-Gerhard HELLER $^{4}$ and Battal ÇIPLAK ${ }^{1}$ \\ 1Akdeniz University, Faculty of Sciences, 07058 Antalya, Turkey; e-mails: kaya_sarp@hotmail.com; ciplak@akdeniz.edu.tr \\ ${ }^{2}$ Institute of Biodiversity and Ecosystem Research, 1 Tsar Osvoboditel Boul., 1000 Sofia, Bulgaria; e-mail: dchobanov@gmail.com \\ ${ }^{3}$ Biology Students Association - BIUS, Roosevetov trg 6, HR-10000 Zagreb, Croatia; e-mail: skejo.josip@gmail.com \\ ${ }^{4}$ Grillenstieg 18, 39120 Magdeburg, Germany; e-mail: heller.volleth@t-online.de
}

Key words. Orthoptera, Tettigoniidae, Psorodonotus, systematics, taxonomy, phylogeny, Balkan Peninsula

\begin{abstract}
A review of the Balkan representatives of the genus Psorodonotus was made with the aim of revealing the relationships between taxa and their systematic arrangement. For this purpose we used morphological (qualitative and quantitavive), acoustic (amplitude-temporal song parameters) and molecular (mtDNA COI gene sequence) data. The analyses and comparisons with other taxa of Psorodonotus support the distinction of three species occurring on the Balkan Peninsula: P. fieberi, P. illyricus and P. macedonicus. Analysis of the COI sequences suggested the following relationships: outgroups $+($ P. illyricus $+(P$. fieberi $+(P$. macedonicus $+P$. caucasicus))). All available information on the distribution of the Balkan taxa was synthesized and mapped.
\end{abstract}

\section{INTRODUCTION}

Brunner von Wattenwyl (1861) established the genus Psorodonotus (originally a subgenus of Decticus) for $P$. pancici Brunner von Wattenwyl, 1861 (presently regarded a synonym of $P$. fieberi (Frivaldszky in Fieber, 1853) and the then known Pterolepis fieberi and Pterolepis venosa Fischer de Waldheim, 1839 (described under Peltastes Fischer de Waldheim, 1839, which was recognized by its author as a preoccupied name; Fischer de Waldheim, 1846). Later on, Brunner von Wattenwyl (1882) included in this genus also Pterolepis specularis Fischer de Waldheim, 1839 (also described under Peltastes). At present, the genus is thought to include 22 valid taxa (15 species) (Eades et al., 2014; Kaya et al., 2014), distributed in the mountainous regions of the Caucasus, Anatolia and the Balkan Peninsula. The highest diversity of species is concentrated in Eastern and Northeastern Anatolia and the Caucasus-Transcaucasus region. Three valid taxa are presently known from the Balkan Peninsula: Psorodonotus fieberi fieberi (Frivaldszky in Fieber, 1853), Psorodonotus fieberi illyricus Ebner, 1923 and Psorodonotus fieberi macedonicus Ramme, 1931. After their description, significant discrepancies existed between authors concerning the taxonomic status and systematics of the Balkan taxa. The taxa are regarded either as subspecies of two species (e.g., Ramme, 1931; Mikšić, 1965; Harz, 1969), separate species (Ramme, 1951) or subspecies of a single species (Heller, 1988; Eades et al., 2014). Most of the cited studies rely on morphological criteria. Heller (1988) used parameters of the male calling song in addition to general morphology to define the subspecies relationships of the three taxa, a view that is currently accepted (Eades et al., 2014). Recent studies on related taxa in Anatolia (Ünal, 2013; Kaya et al., 2013, 2014; Taylan et al., 2014) revealed new distinct lineages in the genus with morphological and acoustic differences of the same order, which showed significant genetic differences (Kaya et al., data in prep.). Thus, the aim of the present study is to test the hypotheses concerning the taxonomic status of the Balkan taxa and reveal their relationships using molecular, morphological and acoustic data.

\section{MATERIAL AND METHODS}

\section{Sampling}

For the purposes of the present study we concentrated on collecting specimens from at least two mountain areas within the geographically outlined ranges of the known taxa (e.g., Mikšić, 1965; Harz, 1969). The material used for morphological and molecular studies is listed in Appendix 1.

\section{Morphology}

Specimens from the populations sampled were preserved in $70-96 \%$ ethanol in order to preserve original body shape. Upon preliminary identification (according to Ramme, 1951; Mikšić, 1965; Harz, 1969) specimens were arranged into respective taxonomic units (Appendix 1). We examined the morphological characters previously used for discriminating taxa. Respective morpho-structures were photographed, qualitatively examined and measured using a Leica MZ6/DC600 stereomicroscope equipped with a digital camera and Image J v. 1.36 software (http://rsb.info. nih.gov/ij/).

Previously, the Balkan representatives of Psorodonotus were distinguished mainly on their cercal morphology, titillator and ovipositor shape, and pronotum size (Ramme, 1951). Therefore, we conducted a geometric morphometrics analysis of all of these structures except the titillators. Illustrations of the pronotum and

\footnotetext{
* Corresponding author. Authors' contributions: The idea conceived by BÇ; data produced by SK, DPC, JS, KGH, and BÇ; DPC and $\mathrm{BC}$ wrote the paper.
} 
A
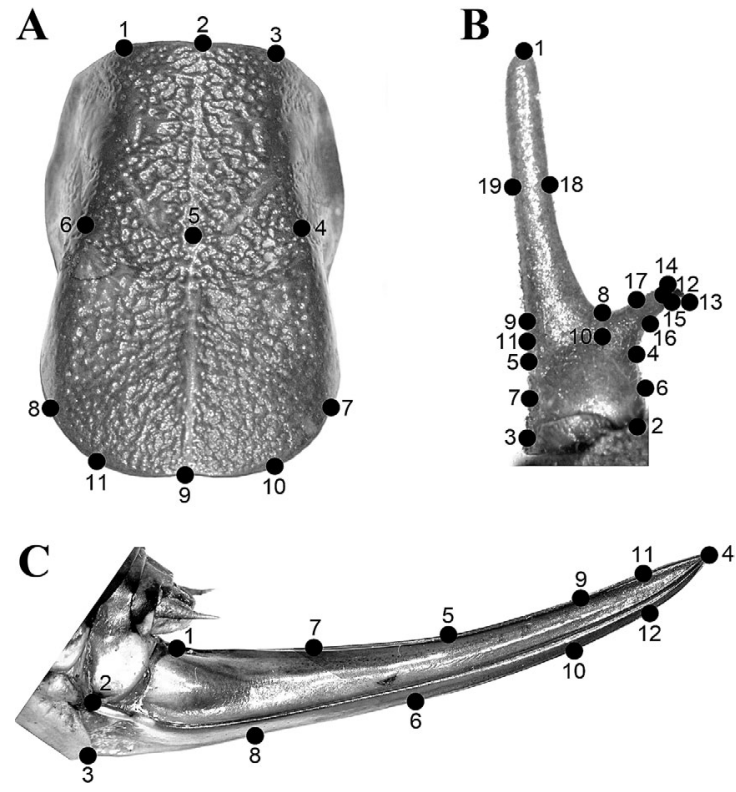

Fig. 1. Position of the homological landmarks on the three structures that were included in the Geometric morphometrics analysis: A - pronotum (P. fieberi); B - male cerci (P. illyricus); $\mathrm{C}$ - ovipositor (P. fieberi).

subgenital plate of males and females, tegmina, cerci and titillators of males and ovipositor of females were prepared for all available specimens (Appendix 1). In the case of uncertainty of the correct position of a structure in the photographs we used an additional image of the same structure. As a result, 54 images (fieberi-18, macedonicus - 12, illyricus - 24) of the male and 35 (fieberi-5, macedonicus - 10, illyricus -20 ) of the female pronota, 88 (fieberi - 20, macedonicus - 19, illyricus - 49) of cerci and 31 (fieberi - 5, macedonicus - 7, illyricus - 19) of ovipositors were prepared. TPS files for each structure were created from images using tpsUtil v.1.26 following Rohlf (2004). Titillators were used only in the descriptive diagnoses. Eleven homologous landmarks for pronota, 19 for cerci and 12 for ovipositors were plotted manually in tpsDIG2 v.1.40 (Rohlf, 2002) according to
Kaya et al. (2013, 2014) (Fig. 1). The intersections marked in the TPS files were aligned using a Procrustes superimposition and matrices of partial warp scores for each structure were generated using MorphoJ v.1.03d (Klingenberg, 2011). Partial warp scores were analyzed using Canonical variate (CV) analysis using the same software.

\section{Song}

Male songs were recorded using the following equipment: (1) electret condenser microphone Knowles BT-1759-000 (with a cut-off at about $45 \mathrm{kHz}$; W. Schulze, Friedrich-Alexander Universität Erlangen-Nürnberg, pers. comm.), equipped with a custom-made preamplifier, connected to a ZOOM H2 handy recorder (Zoom Corporation) (96 kHz sampling rate); (2) Pettersson D500 external microphone (frequency range $1 / 2->100 \mathrm{kHz}$ ) connected to a ZOOM H2 handy recorder; (3) UHER 4200 IC tape recorder with microphone UHER M645.

In addition we used some recordings available in the SysTax database (http://www.biologie.uni-ulm.de/systax/index.html) uploaded by Sigfrid Ingrisch via the DORSA project (http://www. dorsa.de/). For the specimens recorded and recording conditions see Table 1 .

\section{Bioacoustic terminology}

Modified from Heller et al., 2004; Kaya et al., 2014. Calling song: the song produced by an isolated male; phrase: a group of densely arranged song elements or syllables forming main discrete part of the song; syllable: sound produced during one cycle of movements of tegmina (opening - often quiet - and closing - typically loud); here we termed the main distinguishable part of the song a syllable, which may be a single repeated unit of the phrase used by Kaya et al. (2014); element: a distinguishable compact oscillographic component that can be practically measured; syllables repetition rate: reciprocal of the syllable period (unit $\mathrm{Hz}=1 / \mathrm{s}$ ); syllable period: the duration of a syllable and the following silent interval until next syllable starts; syllable duration: the time interval starting from beginning of one repeated unit to its end; impulse: a recognizable undivided transient train of sound waves produced by the stridulatory tooth striking the plectrum (the anal edge of the opposite tegmen).

TABLE 1. Recordings of the male song of Psorodonotus used in this study.

\begin{tabular}{|c|c|c|c|c|c|}
\hline Identification & $\begin{array}{c}\text { Geographic range / } \\
\text { Country }\end{array}$ & Locality, date & $\begin{array}{l}\text { Geographic } \\
\text { position }\end{array}$ & $\begin{array}{l}\text { Recording equip- } \\
\text { ment (Source) }\end{array}$ & Temperature \\
\hline fieberi & $\begin{array}{c}\text { Balkan Mts / } \\
\text { Bulgaria }\end{array}$ & $\begin{array}{l}\text { W Stara Planina Mts, } \\
\text { Midzhur Peak, } 1900 \mathrm{~m} \text {, } \\
9.09 .2012\end{array}$ & $\begin{array}{l}43.40810^{\circ} \mathrm{N} \\
22.66795^{\circ} \mathrm{E}\end{array}$ & $\begin{array}{l}\text { Knowles mic }+ \\
\text { ZOOMH2 }\end{array}$ & $28^{\circ} \mathrm{C}$ \\
\hline macedonicus & $\begin{array}{c}\text { S Pindo-Dinaric Mt } \\
\text { Range / Greece }\end{array}$ & $\begin{array}{c}\text { Ionnina, Epirus, lake near } \\
\text { Metsovon, 27.07.2004 }\end{array}$ & $\begin{array}{l}39.817^{\circ} \mathrm{N} \\
21.133^{\circ} \mathrm{E}\end{array}$ & $\begin{array}{l}\text { UHER M645 + } \\
\text { UHER } 4200 \text { IC }\end{array}$ & $19^{\circ} \mathrm{C}$ \\
\hline macedonicus & $\begin{array}{l}\text { S Pindo-Dinaric Mt } \\
\text { Range / R Macedonia }\end{array}$ & $\begin{array}{c}\text { Bistra Mt., Tonivoda } \\
\text { highland, } 1625-1700 \mathrm{~m} \\
18.07 .2013\end{array}$ & $\begin{array}{l}41.64383^{\circ} \mathrm{N} \\
20.69788^{\circ} \mathrm{E}\end{array}$ & $\begin{array}{c}\text { Pettersson D500 + } \\
\text { ZOOMH2 }\end{array}$ & $24^{\circ} \mathrm{C}$ \\
\hline illyricus & $\begin{array}{l}\text { N Pindo-Dinaric Mt } \\
\text { Range / Montenegro }\end{array}$ & $\begin{array}{c}\text { Durmitor N.P., Pivska } \\
\text { Planina Mt., Jarciste vill., } \\
1500 \text { m, 7.08.1990 } \\
\end{array}$ & $\begin{array}{l}43.13292^{\circ} \mathrm{N} \\
18.96944^{\circ} \mathrm{E}\end{array}$ & $\begin{array}{l}\text { AKG D202+ Ken- } \\
\text { wood KX880HX } \\
\left(\text { SysTAX }^{*}\right) \\
\end{array}$ & $\begin{array}{c}\text { ? }>32^{\circ} \mathrm{C} \text { approximate estimate, rec. } \\
1220\left(27^{\circ} \mathrm{C} \text { room } \mathrm{T}^{\circ} \text { but under }\right. \\
\text { incandescent lamp })\end{array}$ \\
\hline illyricus & $\begin{array}{l}\text { N Pindo-Dinaric Mt } \\
\text { Range / Croatia }\end{array}$ & $\begin{array}{c}\text { Rijeka, Ućka Mt., 1000- } \\
1200 \text { m, } 12.08 .2011 \\
\& \\
\text { Rijeka, Ućka Mt., } \\
21.07 .1979\end{array}$ & $\begin{array}{c}45.29194^{\circ} \mathrm{N} \\
14.20806^{\circ} \mathrm{E} \\
\& \\
45.33^{\circ} \mathrm{N} \\
14.18^{\circ} \mathrm{E}\end{array}$ & $\begin{array}{c}\text { AKG D202+ Ken- } \\
\text { wood KX880HX } \\
\left(\text { SysTAX*) }^{*}\right) \\
\& \\
\text { UHER M645 + } \\
\text { UHER 4200 IC }\end{array}$ & $\begin{array}{c}\text { ? }>32^{\circ} \mathrm{C} \text { approximate estimate, rec. } \\
1016\left(25^{\circ} \mathrm{C} \text { room } \mathrm{T}^{\circ} \text { but under }\right. \\
\text { incandescent lamp }) \\
\& \\
?>32^{\circ} \mathrm{C} \text { approximate estimate }\left(24^{\circ} \mathrm{C}\right. \\
\left.\text { air } \mathrm{T}^{\circ} \text { but animal exposed to sun }\right)\end{array}$ \\
\hline
\end{tabular}

\footnotetext{
*Recording by S. Ingrisch.
} 

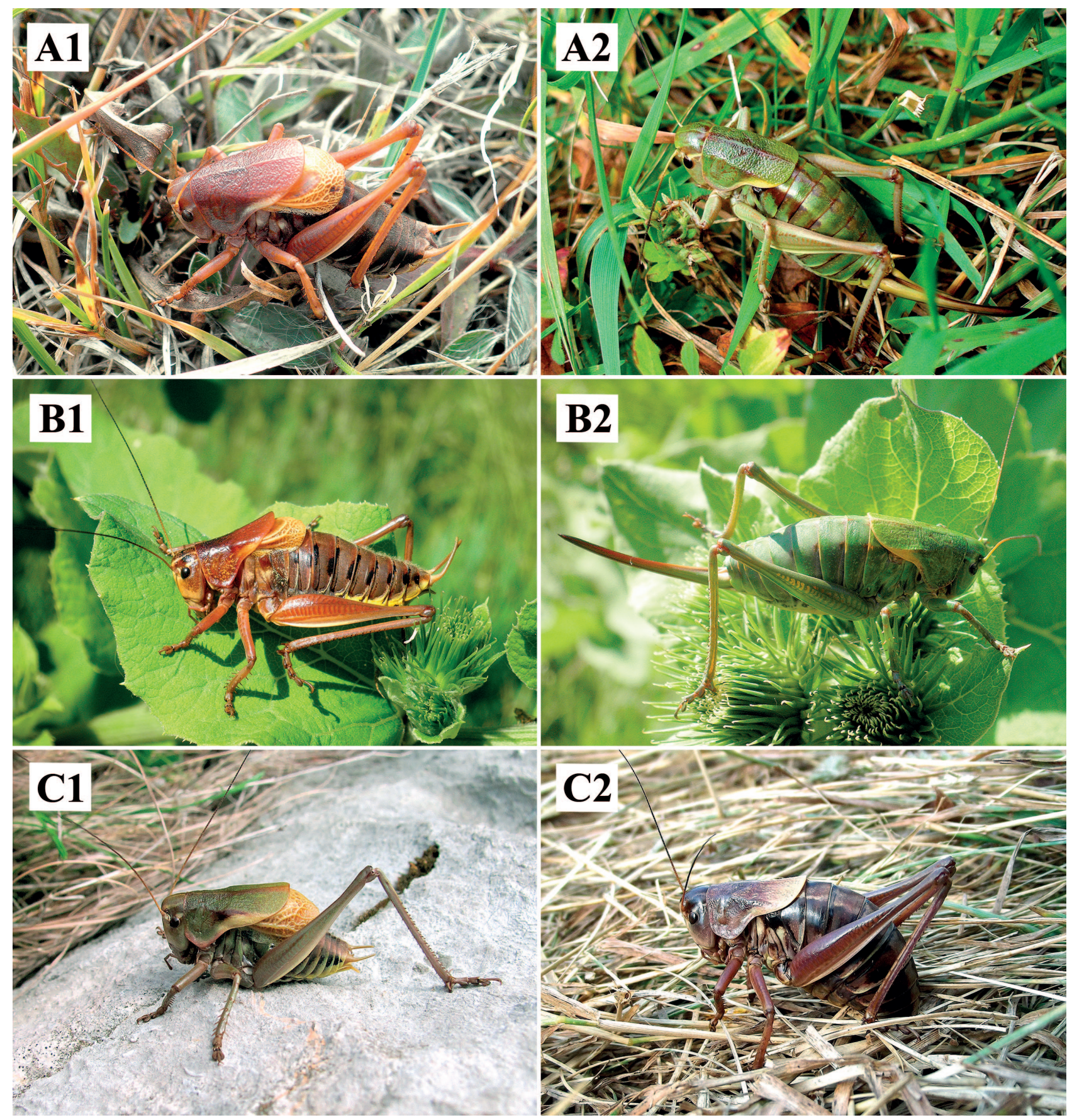

Fig. 2. General appearance of Balkan Psorodonotus (photographed in nature): A - P. fieberi (A1 - male, Bulgaria, W Stara Planina Mts, Vrachanska Planina; A2 - female, Bulgaria, C Stara Planina Mts, Ambaritsa); B - P. macedonicus (B1 - male, B2 - female, both photographed in the Republic of Macedonia, Korab Mt., Strezimir); C - P. illyricus, male (C1 - male, C2 - female, both photographed in Croatia, Obruč).

\section{Song analysis}

For manual and statistical comparisons of temporal song parameters between populations we selected the less variable and easily detectable part of the song: the second/main part of the syllable (see Results: Bioacoustics). As temperature (i.e., body temperature) is the most important factor affecting temporal song parameters in Orthoptera (e.g., Martin et al., 2000; Arias et al., 2012) we produced a subjective manual calibration of the recording temperature for the recordings of $P$. illyricus (see Results).
Molecular sequences and phylogenetic analysis

For determining the phylogenetic relationships between taxa we used Cytochrome c oxidase subunit I (COI) fragments of mitochondrial DNA (mtDNA). This region of mtDNA has revealed phylogenies of high resolution for bushcrickets (e.g., Ullrich et al., 2010) and also provided quality results for Psorodonotus (Kaya et al., in prep.).

Total DNA was extracted from muscle tissue using proteinase $\mathrm{K}$ digestion followed by the standard salt/isopropanol method (Aljanabi \& Martinez, 1997). The universal primers forward C1-J-1718 or C1-J-1751 and reverse TL2-N-3014 were used to amplify the COI fragments (for the details of the structure of the 

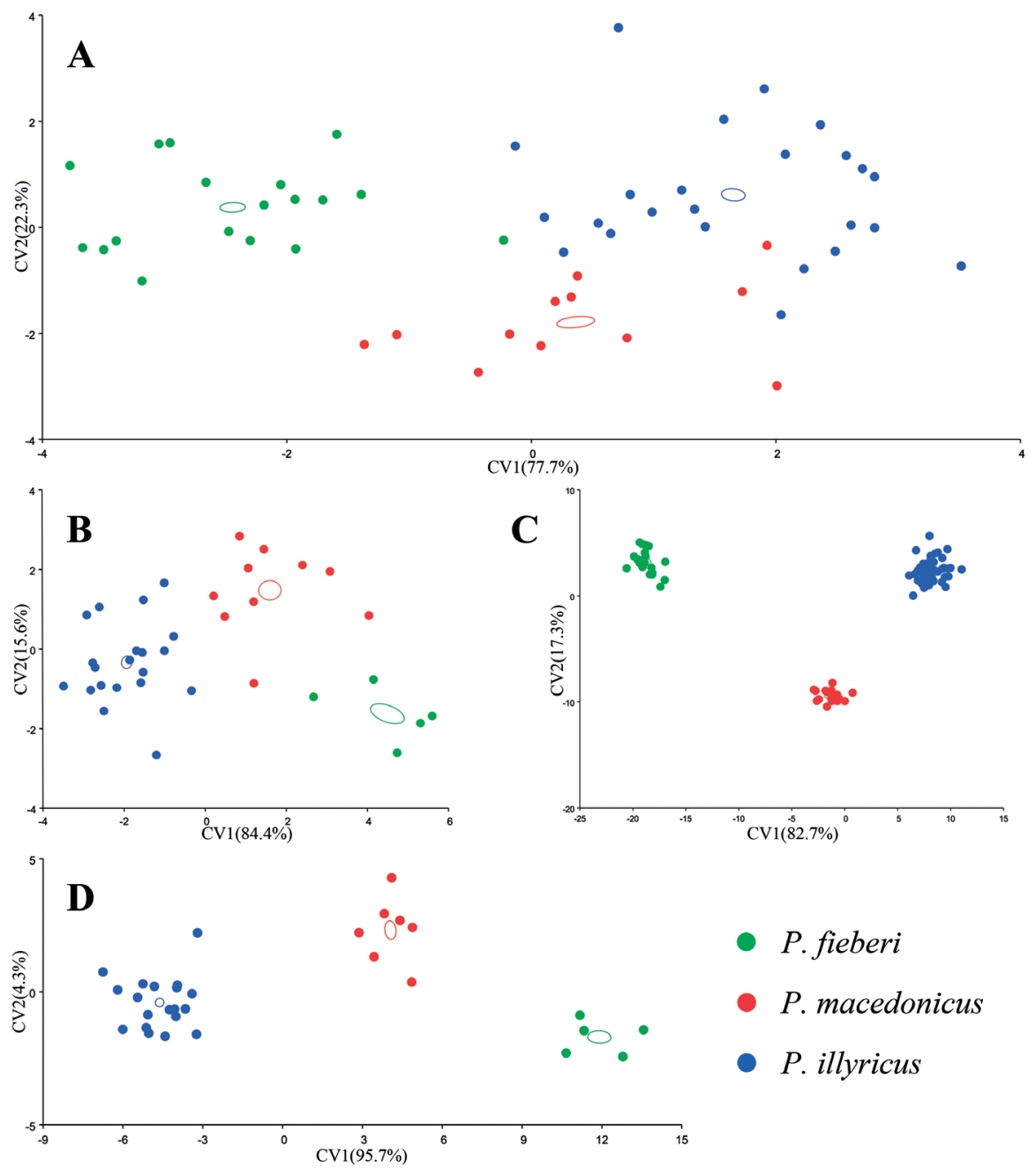

Fig. 3. Graph of CV analysis of centroid sizes of the morphological structures of Balkan Psorodonotus: A - male pronotum; B - female pronotum; $\mathrm{C}$ - male cerci; $\mathrm{D}$ - ovipositor.

primers see Simon et al., 1994). Amplification was performed in a $50-\mu 1$ volume containing $0.3 \mu \mathrm{l}$ of each primer $(100 \mu \mathrm{M}), 1 \mu \mathrm{l}$ dNTP mix (10 mM), $2 \mu 150 \mathrm{mM} \mathrm{MgCl} 2,5 \mu 1$ 10X Platinum PCR buffer (containing $200 \mathrm{mM}$ Tris- $\mathrm{HCl}$ [pH 8.4], $500 \mathrm{mM} \mathrm{KCl}$ ), $1.25 \mathrm{U}$ Platinium TaqDNA polymerase (Invitrogen) and 0.5-1 $\mu 1$ of 50-70 ng template DNA. Temperature cycling was carried out in an Eppendorf Mastercycler Personal. Amplification of the two fragments involved an initial cycle of denaturation at $94^{\circ} \mathrm{C}$ for $1 \mathrm{~min}$, and 35 subsequent cycles of $94^{\circ} \mathrm{C}$ for $40 \mathrm{~s}$, annealing temperature at $49^{\circ} \mathrm{C}$ for $30 \mathrm{~s}$, extension temperature $72^{\circ} \mathrm{C}$ for 90 $\mathrm{s}$, followed by a final extension step of $72^{\circ} \mathrm{C}$ for $10 \mathrm{~min}$. Double-stranded sequence analysis (performed on a $23 \mathrm{ABI} 3730 \mathrm{XL}$ DNA analyzer) and purifications were done by the Macrogen sequencing service (Macrogen Inc.). Nucleotide sequences of each unique haplotype identified in this study were deposited in the GenBank database under the Accession Numbers given in Appendix 3.

The sequences were aligned manually in Sequencher v. 4.1 (Gene Codes Corporation) and checked manually by eye. DnaSP v. 5 (Librado \& Rozas, 2009) was used to determine unique haplotypes. The haplotype matrix was prepared using MEGA v. 5 (Tamura et al., 2011). A maximum parsimony (MP) analysis was carried out with 100 random additions following the heuristic search approach and the tree bisection-reconnection (TBR) algorithm using PAUP v. 4.10b (Swofford, 2000). A 10,000 non-parametric bootstrap resampling was used to assess the branching confidenc- es (Felsenstein, 1985). The parameters and best fit model were estimated using jModelTest v. 0.1.1. (Guindon \& Gascuel, 2003; Darriba et al., 2012). The selected model was implemented in maximum likelihood (ML) and Bayesian phylogenetic inference (BI) analyses. ML was performed using a heuristic search procedure with TBR branch swapping and as-is addition replicates using PAUP v 4.10b. Nonparametric bootstrapping (Felsenstein, 1985 ) was used to evaluate the support of nodes based on 1000 pseudoreplicates analyzed using ML. BI analysis was carried out in MrBayes v. 3.1.2 (Ronquist \& Huelsenbeck, 2003; Ronquist et al., 2005) using four simulations of Markov chains, 2,000,000 generations and sampling every 100 generations. The software tool TRACER v. 1.5 (see Rambaut et al., 2014) was used to examine the parameters and determine the number of trees needed to reach stationarity. BI posterior branch probabilities were calculated using the majority rule consensus of the sampled trees, excluding the first 200 trees as burn-in. P. specularis, $P$. venosus and $P$. caucasicus were chosen as out groups. Pairwise genetic distances of species were calculated using MEGA.

\section{RESULTS}

\section{Morphology}

Preliminary identification of the populations sampled fitted the data from earlier sources very well (e.g., Ramme, 1951; Mikšić, 1965; Harz, 1969). Specimens also conform 

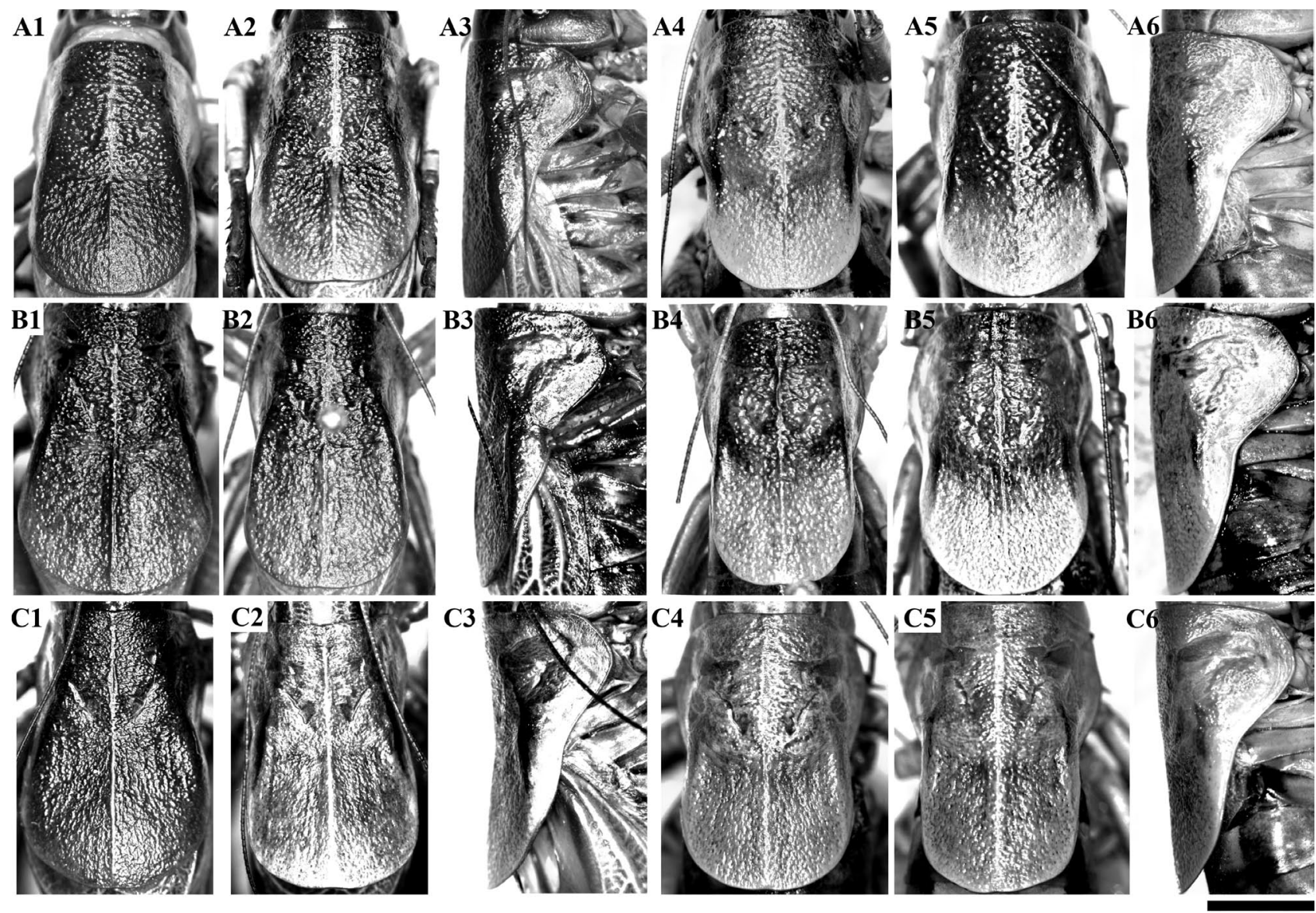

Fig. 4. Pronota of Balkan Psorodonotus (1-3-males, 4-6-females; 1, 2, 4, 5-dorsal, 3, 6- lateral views): A - P. fieberi (Bulgaria, Belassitsa Mt.); B - P. macedonicus (B2 - Greece, Oiti Mt.; the rest - Republic of Macedonia, Bistra Mt.); C - P. illyricus (Croatia, N.P. Sjeverni Velebit). Scale $=5 \mathrm{~mm}$.

with the Psorodonotus caucasicus species group as defined by Kaya et al. (2013), which may be characterized morphologically by the dorsal surface of the pronotum being distinctly rugose but less so than in the venosus species group (smooth or slightly wrinkled in the specularis group). For their general appearance see Fig. 2. Graphs of the results of the $\mathrm{CV}$ analyses of matrices of partial warp scores recorded for male and female pronota, cerci and ovipositors are presented in Fig. 3 .

$\mathrm{CV}$ analysis of male and female pronota (Fig. 3A, B) revealed significant variation within populations and a possible smooth transition between taxa, which is supported by the results of visual observations, which did not reveal clear distinctions between the extremes of variation, except in the short metazona of males of P. fieberi (compare Fig. 4). Combination of the results of the CV1 and CV2 analyses of the male pronotum separated P. fieberi from the other two taxa and revealed an overlap between $P$. macedonicus and P. illyricus (Fig. 3A). CV analysis of the partial wrap scores for female pronota (Fig. 3B) revealed three bordering but non-overlapping clusters (Mahalanobis Distance, $\mathrm{MD}=3.96$ [macedonicus - illyricus], 4.24 [fieberi - macedonicus], 6.55 [fieberi-illyricus], $\mathrm{p}$ [10,000 permutation rounds] $<<0.05$ ), while, although the male pronota (Fig. $3 \mathrm{~A})$ were more similar, nevertheless the analysis also revealed three clusters $(\mathrm{MD}=2.73$ [macedonicus - illyricus],
3.54 [fieberi - macedonicus], 4.10 [fieberi - illyricus], p $<<0.05$ ).

CV analyses of male cerci (Fig. 3C) and the ovipositor (Fig. 3D) indicated three clear clusters, representing each of the existing taxa. Mahalanobis distances between taxa for cerci are 15.18 for macedonicus - illyricus, 21.46 for fieberi-macedonicus and 26.93 for fieberi - illyricus (p $<<0.05$ ) and those for ovipositors are 8.82 for macedonicus - fieberi, 9.09 for macedonicus - illyricus and 16.58 for fieberi-illyricus $(\mathrm{p}<<0.05)$. Male cerci (Fig. 5A2, A3, B3, B4, C2-4) are clearly qualitatively different although some specimens of P. fieberi and P. macedonicus are similar in this character and there is a clear transition in the shape of the ovipositors (Fig. 6A1, A2, B1, B2, C1, C2). In addition, there is a transition between taxa in the shape of the tegmina of males (Fig. 5A1, B1, B2, C1) and subgenital plate of males (Fig. 5A4, A5, B5, B6, C5, C6) and females (Fig. 6A3, B3, B4, C3-5), whereas the titillators (Fig. 7) were more useful for distinguishing taxa.

\section{Bioacoustics}

Acoustically, the Psorodonotus cancasicus group is characterized by a song consisting of syllables (monosyllabic phrases if compared to the other two species groups of this genus) that are composed of two isolated elements (possibly resulting from a step-interrupted closing move- 


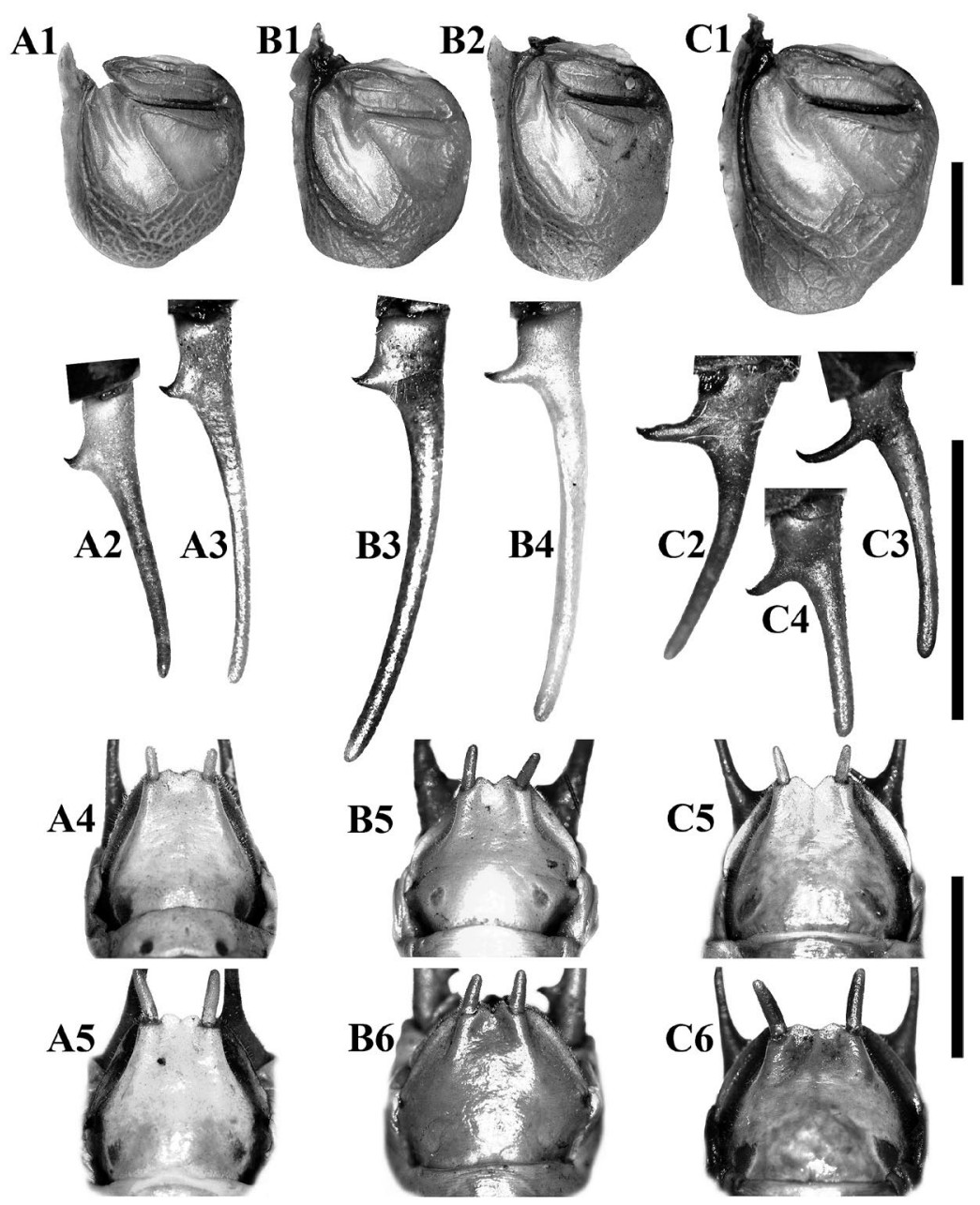

Fig. 5. Morphology of male tegmina (A1, B1, B2, C1), cerci (A2, A3, B3, B4, C2, C3, C4) and subgenital plate (A4, A5, B5, B6, C5, C6) of Balkan Psorodonotus: A - P. fieberi (A3 - Bulgaria, Stara Planina Mts; the rest - Bulgaria, Belassitsa Mt.); B - P. macedonicus (B4 - Montenegro, Bjelasica Mt.; the rest - Republic of Macedonia, Bistra Mt.); C - P. illyricus (C2 - Montenegro, Žabljak; C3 - Bosnia and Hercegovina, Donje Bare; the rest - Croatia, N.P. Sjeverni Velebit). Scale $=5 \mathrm{~mm}$.

ment of the tegmina). This is the main difference between the $P$. caucasicus group and the $P$. specularis and $P$. venosus groups, in which two or more syllables are grouped into phrases (oscillographically consisting of three or more song elements) (Kaya et al., 2013, 2014).

The syllable (Fig. 8) consists of a quiet (low amplitude) first element, which may be compact ( $P$. fieberi, $P$. macedonicus) or separated into two parts (P. illyricus), and after a short silent interval, a second (main) element. The main element starts with a crescendo of dense impulses, in which the maximum amplitude is reached and then the impulses become sparser at the end of the element. The main element may finish abruptly (in P. illyricus) or be followed by a few isolated impulses or after-clicks ( $P$. fieberi and $P$. macedonicus). There is a tendency for the number of after-clicks to increase with decrease in body temperature. Syllable length and syllables repetition rate depend on temperature. As all the recordings of $P$. illyricus obtained in this study do not seem to reflect the real body temperature (the animals were exposed either to sun or to the light from an incandescent lamp, see Table 1) the approximate body temperature during recordings was determined by comparing the data of Keuper et al. (1988), Weidemann (1993) and Jatho et al. (1994) and the temporal parameters in relation to the temperature change recorded in $P$. macedonicus. Weidemann (1993) records a 90-120 ms length of the main syllable element of $P$. illyricus at about $24^{\circ} \mathrm{C}$, which we find the most reliable measurement. Furthermore, some differences in the syllables repetition rate were recorded (see Fig. 8, Table 2).

\section{Molecular data and phylogeny}

After alignment and trimming, the final length of COI sequences was $1111 \mathrm{bp}$. Of the 1111 aligned sites, 873 sites were constant, 238 were variable, and 178 were parsimony informative. We used 73 ingroup and 4 outgroup sequences, that represented 40 different haplotypes. Of those 15 ingroup and 4 outgroup haplotypes were used in the phylogenetic analyses. As early analyses indicated for haplotypes of $P$. caucasicus clustering within the haplotypes of the Balkan populations, one haplotype per $P$. specularis and $P$. venosus was used as the outgroup in later analyses and MP, ML and BI analyses with this setting are presented. jModeltest suggested the Tamura-Nei model based on the AIC value. 


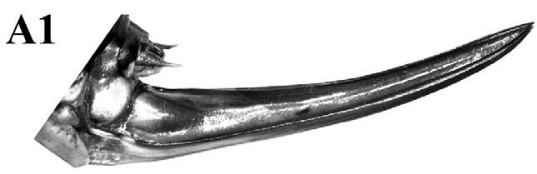

B1

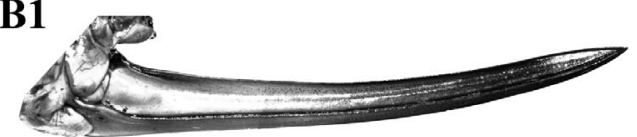

C1

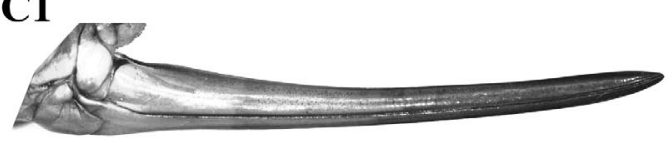

A3
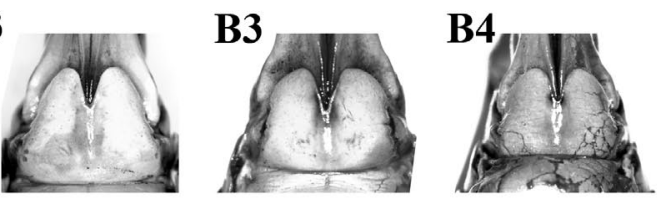

A2

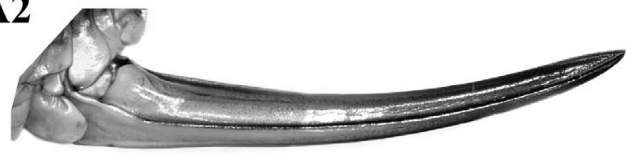

B2

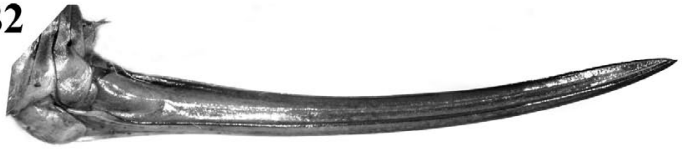

C2
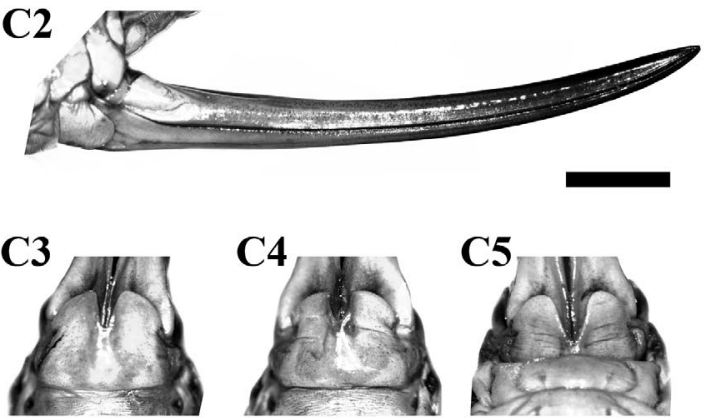

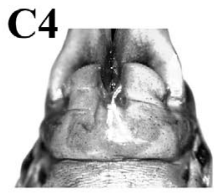

C5

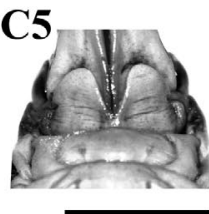

Fig. 6. Morphology of female ovipositor (A1, A2, B1, B2, C1, C2) and subgenital plate (A3, B3, B4, C3-C5) of Balkan Psorodonotus: A - P. fieberi (Bulgaria, Belassitsa Mt.); B - P. macedonicus (B1 - Republic of Macedonia, Bistra Mt; B2 - Greece, Metsovon); $\mathrm{C}-$ P. illyricus (Croatia, N.P. Sjeverni Velebit; Note: in C5 the base of plate is covered by the seventh sternite). Scale $=5 \mathrm{~mm}$.

The MP, ML and BI analyses resulted in similar tree topologies (Fig. 9). Most of the nodes were constant in all trees with high bootstrap (MP and ML) or posterior probabilities (BI) supporting the following results: (1) P. caucasicus forms a clade together with the three Balkan taxa; (2) P. caucasicus and P. macedonicus form a monophyletic clade; (3) monophyly of haplotypes of each taxon. MP, ML and $\mathrm{BI}$ trees differed in topology for the relationships of the three main clades, (P. caucasicus $+P$. macedonicus $)$, P. fieberi and P. illyricus. The BI indicated [((caucasicus + macedonicus $)+$ fieberi $)+$ illyricus $]$ whereas the MP/ML trees indicated trichotomy. Pairwise genetic distances among the three Balkan phylogroups (36 haplotypes) corrected by the Tamura-Nei model were as follows (net between mean/ between group mean): fieberi - illyricus $=0.069 / 0.080$, fieberi - macedonicus $=0.072 / 0.080$, macedonicus - illyricus $=0.078 / 0.085$.

\section{Discussion and taxonomic conclusions}

So far, the Balkan populations of Psorodonotus have been treated in various systematic studies, either as three distinct species, three subspecies of two species, or subspecies of a single variable species (Ramme, 1931, 1951; Mikšić, 1965; Harz, 1969; Heller, 1988). New recently accumulated data indicate a better view of speciation within Psorodonotus, which in allopatric taxa have resulted in weaker morphological and acoustic differentiation, though genetic differences frequently point to early lineage separation (Kaya et al., in prep.). On the other hand, sympatric/ parapatric taxa are clearly distinct (Kaya et al., 2014). Present data revealed good morphological distinction between P. fieberi, P. macedonicus and P. illyricus, similar to or even bigger than that recorded within well separated lineages of the $P$. venosus (Kaya et al., 2013) and P. specularis
(Kaya et al., 2014) species groups. Although the differences in song between the Balkan taxa are weaker (this paper) nevertheless they are within the interspecific range of distinction of the other lineages (see last citations). This is not surprising as divergence in song is usually slower in the case of allopatry (Heller, 2006; Çıplak et al., 2009). Most important support for the distinctiveness of the Balkan species comes from molecular data as all of the phylogenetic analyses confirmed the species are monophyletic. In addition, pairwise genetic divergence between species is high, about or above the mean for closely related allo-/parapatric orthopterans (e.g., Allegrucci et al., 2005; Shapiro et al., 2006) and even about the mean between-families distances recorded for some insect orders (Hebert et al., 2003). Our data indicated that the significant genetic distances between selected taxa were largest between $P$. macedonicus and $P$. illyricus. Interestingly, in all trees $P$. caucasicus is a sister group of $P$. macedonicus.

Our results do not support the opinion of Mikšić (1965) and Ingrisch \& Pavićević (2012) that the populations in Montenegro are intermediate forms between P. illyricus and $P$. macedonicus. The specimens from Eastern Montenegro (Bjelasica Mt. S of Tara River) identified here as P. macedonicus grouped within the latter together with specimens from Western Macedonia and Northern Greece, while specimens from Northern Montenegro ( $\mathrm{N}$ of Tara River) fit $P$. illyricus and group within it in the CV analysis. According to Mikšić (1965) the lengths of the cerci of specimens from Montenegro differ and the titillator shape is intermediate. Though the apical parts of cerci were indeed longer in specimens from Northern Montenegro and Southern Bosnia and Hercegovina (see Fig. 5C2, C3), the shape of their bases and the cercal spine clearly put these 


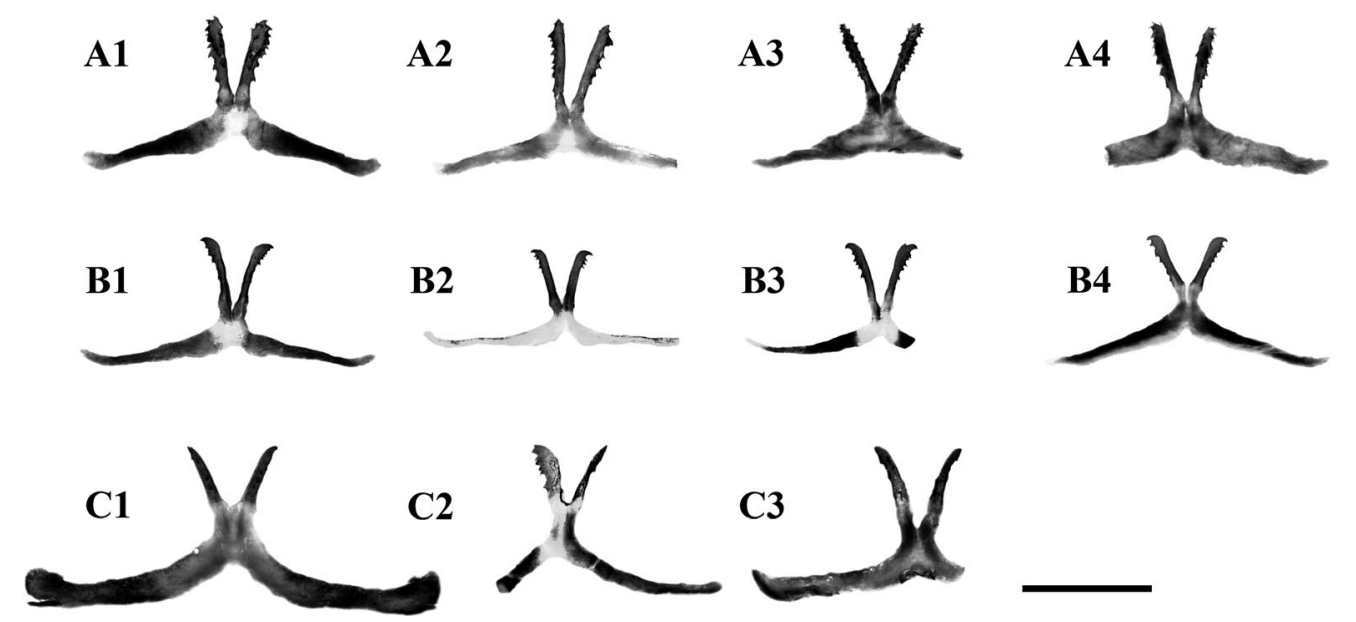

Fig. 7. Morphology of male titillators of Balkan Psorodonotus: A - P. fieberi (A1, 2 - Bulgaria, Belassitsa Mt.; A3, A4 - Bulgaria, Stara Planina Mts); B - P. macedonicus (B1, 2 - Republic of Macedonia, Bistra Mt.; B3 - R Macedonia, Jablanica Mt.; B4 - Montenegro, Bjelasica Mt.); C - P. illyricus (C1 - Croatia, Poštak Mt.; C2 - Bosnia and Hercegovina, Donje Bare; C3 - Montenegro, Šavnik). Scale $=2 \mathrm{~mm}$.

animals within P. illyricus. Our small sample from this area cannot rule out the absence of intermediate forms. However all specimens studied could be related to a respective taxonomic unit. In terms of the male titillators, the specimens of $P$. illyricus and $P$. macedonicus in general differed with shorter and wider apical titillator arms in P. illyricus and more prominent with longer and stouter basal arms in P. illyricus (compare Fig. 7B with $\mathrm{C}$ ). The gracile basal arms of the titillator of a specimen of P. illyricus from Bosnia and Herzegovina (Fig. 7C2; note the left apical arm is distorted) may be due to the weak sclerotization. Its geographic origin between Montenegro and Croatia indicates rather intraspecific variation than intermediate (i.e., hybrid) populations as stated by Mikšić (1965) and Ingrisch \& Pavićević (2012) for specimens from Montenegro. In addition, differences in the shapes of the titillators of $P$. illyricus and P. macedonicus are similar to those among the latter taxa and other representatives of the caucasicus species group ( $P$. ebneri, $P$. caucasicus) or even representatives of other species groups (e.g., P. venosus, $P$. specularis, etc.) (compare Ramme, 1951; Kaya et al., 2013, 2014). On the other hand, the shape of the titillator of $P$. fieberi (Fig. 7A) clearly distinguished this species.

Both the geometric morphometrics and molecular phylogeny presented in this study confirm the species status of the three taxa on the Balkan Peninsula: P. fieberi, P. illyricus and $P$. macedonicus. Our results also indicate an interesting phylogeographic pattern in the $P$. caucasicus species group with $P$. caucasicus placed within the Balkan lineage. However, in order to reveal the evolutionary history of the latter a comprehensive phylogeographic study based on mitochondrial and nuclear DNA phylogenetic analyses (Kaya et al., in prep.) and ecological niche modelling is needed.

\section{Psorodonotus fieberi (Frivaldszky in Fieber, 1853)}

Figs 2A, 3, 4A, 5A, 6A, 7A, 8A, 9, 10, Tables 2, 3

Pterolepis fieberi: Fryvaldszky [Frydvaldsky] in Fieber, 1853: 154.

Psorodonotus pancici: Brunner von Wattenwyl, 1861: 7(291).

Psorodonotus fieberi: Herman, 1874: 208.

Psorodonotus fieberi: Brunner von Wattenwyl, 1882: 367 (incl.

P. pancici, syn. n.).

Psorodonotus fieberi fieberi: Ebner, 1923: 250, 251.

Psorodonotus fieberi: Mikšić, 1965: 203-213.

Psorodonotus fieberifieberi: Heller, 1988: 134, 135 (sensu novo).

\section{Morphological description}

See the references above; Harz, 1969 (as fieberi fieberi). Bioacoustics: Heller, 1988 (as fieberi fieberi).

General description and diagnosis

Males usually brownish (brownish-violet), females mostly green (rarely females also brown) (Fig. 2A1, 2). Male pronotal (Fig. 4A1-3) disc is strongly rugose (with distinct dense dents), less widened in the metazona (but some exceptions are present). The metazona is short with the transverse furrow behind the middle of the pronotum (rarely at its middle) and the hind pronotal sulcus reaching the median keel slightly before the middle of the pronotum. The female pronotal (Fig. 4A4-6) disc also usually with short and narrow metazona (though may be similar to that of male), less rugose than in male but more than in other species. Male tegmina (Fig. 5A) usually reach the third tergite. Male cerci (Fig. 5A2, 3) longer than cerci of P. illyricus and shorter than those of P. macedonicus, apical part

TABLE 2. Differences in the structure and amplitude-temporal song pattern of Balkan Psorodonotus.

\begin{tabular}{lcccc}
\hline Taxon & Syllables repetition rate at $23-28^{\circ} \mathrm{C}$ Length of main element at $\sim 25^{\circ} \mathrm{C}$ & Presence of after-clicks & Number of after-clicks \\
\hline fieberi & $(? 0.2) 0.3-0.6 \mathrm{~Hz}$ & $70-100 \mathrm{~ms}$ & yes & $>1$ \\
macedonicus & $0.4-1 \mathrm{~Hz}$ & $50-80 \mathrm{~ms}$ & yes & $>1$ \\
illyricus & $1-3 \mathrm{~Hz}$ & $90-120(-150 ?) \mathrm{ms}$ & no/yes & $0-1$ \\
\hline
\end{tabular}


A

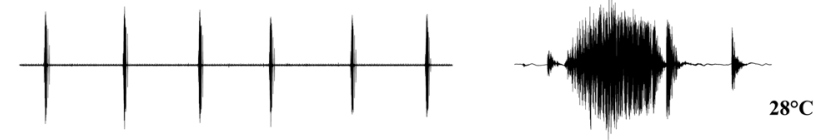

B1

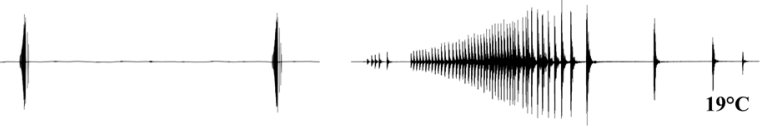

B2

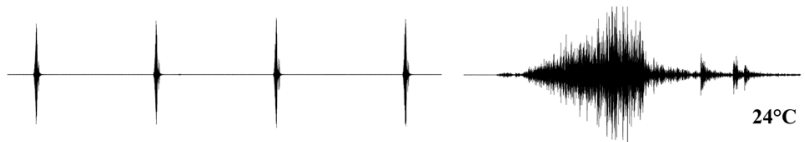

C1
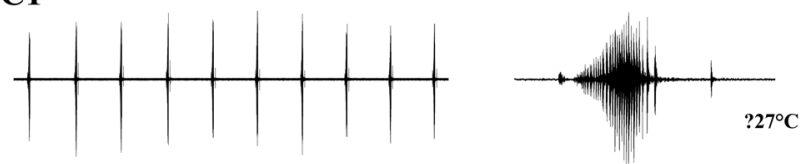

$\mathrm{C2}$
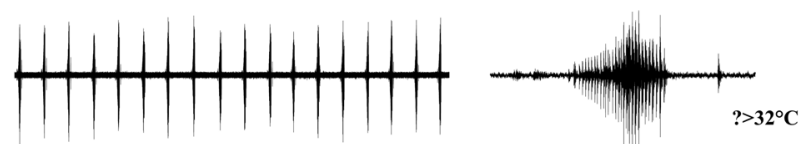

C3
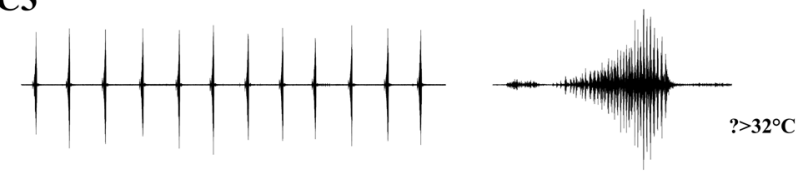

$\underline{1 s}$

$20 \mathrm{~ms}$

Fig. 8. Oscillograms of the song of Balkan Psorodonotus, recorded at different temperatures and two different speeds: A $-P$. fieberi (Bulgaria, W Stara Planina Mts, Midzhur Peak); B - P. macedonicus (B1 - Greece, Ioannina, Epirus, lake near Metsovon, rec. PSMA0401; B2 - Republic of Macedonia, Bistra Mt., Carevec pass); $\mathrm{C}-$ P. illyricus (C1 - Montenegro, Durmitor N.P., Pivska Planina Mt., Jarćiśte vill., rec. S. Ingrisch; C2 - Croatia, Rijeka, Ućka Mt., rec. S. Ingrisch; C3 - Croatia, Rijeka, Ućka Mt., rec. PSIL 7904).

(from the tooth to the tip) over 2 times and up to 3.5 times longer than the basal part (from base to the tooth); base of cerci 3-4 times wider than the apex; cercal tooth similar in length but usually wider than that of $P$. macedonicus. Titillator (Fig. 7A) wider apically with strong teeth distributed in two or more rows; basal arms short, wide medially and narrowing laterally. Female subgenital plate (Fig. 6A3) elongated with a moderately deep incision being up to onethird of the length of the plate and forming narrow apical lobes. Ovipositor (Fig. 6A1, 2) variable in curvature and length $(23.5-32 \mathrm{~mm}$; Harz, 1969) but is usually stouter than in other taxa, wide at its base and gently narrowing towards the tip. Average length of ovipositor is the shortest among these three taxa (Table 3). Hind femora in the specimens studied contrary to the statement by Mikšić (1965) did not differ significantly in length (but mean values lower than in other taxa) or in the ratio length: width from those of the other two taxa (Table 3; see also Harz 1969).

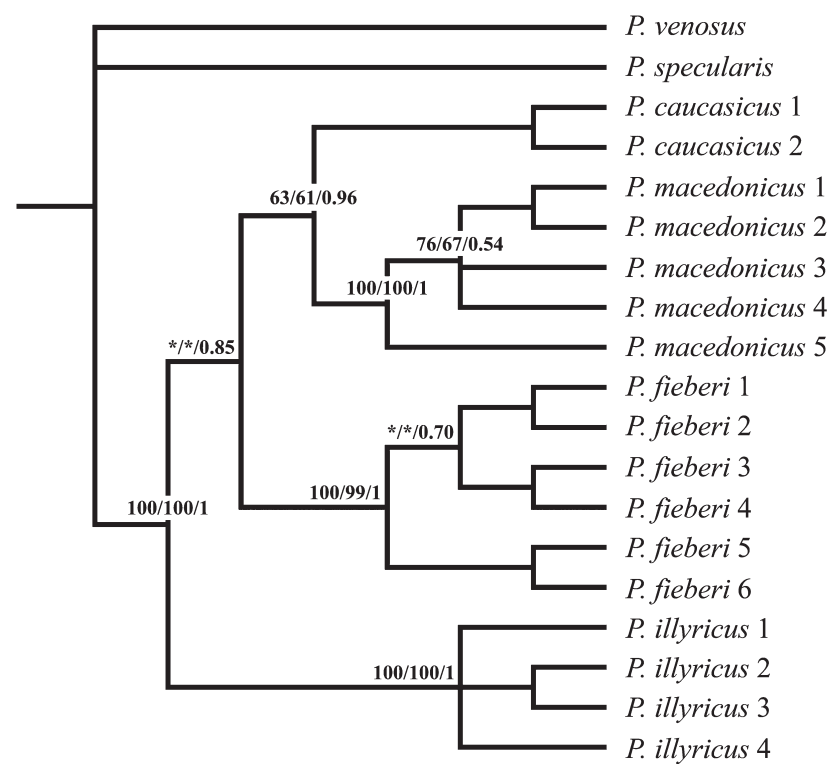

Fig. 9. Phylogenetic tree based on the Bayesian analysis of 15 haplotypes of Balkan and four haplotypes of Anatolian Psorodonotus. MP/ML bootstrap proportions (values $>50$ ) and $\mathrm{BI}$ internode posterior probabilities (values $>0.50$ ) are shown on BIresolved internodes.

Song (Fig. 8A) consists of sparsely repeated syllables $\left(0.3-0.6 \mathrm{~Hz}\right.$ at $\left.23-28^{\circ} \mathrm{C}\right)$ that contain a compact main element and well detached after-clicks.

\section{Distribution}

Fig. 10, Appendix 2. P. fieberi occurs in the Balkan (Stara Planina) Mountains, Macedonian-Thracian Massif (Rhodopean Mts s.1.) and the eastern arc of the Dinaric Mountain Range (Bulgaria, E Serbia, E Republic of Macedonia, NE Greece). The border of its range in the North is the Danube River valley, in the East - the lower parts of the Stara Planina Mts and Rhodope Mts, and in the South - the southern slopes of the Macedonian-Thracian Massif. In the West the known range of the species, mostly according to Mikšić (1965), borders the ranges of P. macedonicus and $P$. illyricus, approximately following the valleys of the Vapa, Lim, Drina, Ibar (Ibër), Sitnicë, Pchinja and Vardar Rivers, but it is not known where this border connects with the Pchinja and Sitnicë valleys. The exact border of its range, e.g., the locality “Tara Mt." (Grebenshchikov, 1950; Mikšić, 1965) is not well defined.

The locality "Kasikoparan (Armenien)" (present Turkey) recorded by Ebner (1923; as P. fieberi fieberi) and "Armenia" (Jacobson \& Bianchi, 1905) is herewith referred to $P$. caucasicus (Fischer von Waldheim, 1846). The record by Ebner (1923) from "Kalakend, Karabagh" (Kalakend Settlement in Nagorno-Karabakh Republic) is also possibly for $P$. caucasicus. The record by Ebner (1923) of P. illyricus from Bulgaria may either be a misidentification or the result of wrong labeling.

This species inhabits open grass-herbaceous plant associations, usually with Juniperus communis alpina, the bushes of which it uses for protection. It occurs within the altitudinal range 1100-2300/2400 m alt. (usually between 1500 and $2200 \mathrm{~m}$ ). 
TABLE 3. Measurements recorded for some of the morphological structures of Balkan Psorodonotus. Measurements are given in mm: first row - Min-Max values, in brackets - Average \pm Standard deviation and number.

\begin{tabular}{|c|c|c|c|c|c|c|}
\hline & \multicolumn{2}{|c|}{ P. fieberi } & \multicolumn{2}{|c|}{ P. macedonicus } & \multicolumn{2}{|c|}{ P. illyricus } \\
\hline & males & females & males & females & males & females \\
\hline Pronotum length & $\begin{array}{c}11.1-12.7 \\
(12.0 \pm 0.5, \mathrm{n}=16)\end{array}$ & $\begin{array}{c}11.9-12.7 \\
(12.4 \pm 0.3, n=5)\end{array}$ & $\begin{array}{c}10.1-13.7 \\
(12.2 \pm 1.0, \mathrm{n}=11)\end{array}$ & $\begin{array}{c}11.9-13.6 \\
(12.8 \pm 0.6, n=11)\end{array}$ & $\begin{array}{c}11.6-14.6 \\
(12.7 \pm 0.7, \mathrm{n}=25)\end{array}$ & $\begin{array}{c}12.3-14.3 \\
(13.1 \pm 0.4, n=19)\end{array}$ \\
\hline Hind femur length & $\begin{array}{c}20-22.5 \\
(20.8 \pm 0.7, \mathrm{n}=14)\end{array}$ & $\begin{array}{c}21.5-23.5 \\
(22.5 \pm 0.9, n=4)\end{array}$ & $\begin{array}{c}20.5-24 \\
(22.4 \pm 1, \mathrm{n}=8)\end{array}$ & $\begin{array}{c}21-26 \\
(23.6 \pm 1.4, \mathrm{n}=12)\end{array}$ & $\begin{array}{c}19-25.4 \\
(22.6 \pm 1.7, \mathrm{n}=24)\end{array}$ & $\begin{array}{c}21.6-27 \\
(23.5 \pm 1.1, n=24)\end{array}$ \\
\hline $\begin{array}{l}\text { Ratio length: width } \\
\text { of hind femur }\end{array}$ & $\begin{array}{c}4.6-5.7 \\
(5.2 \pm 0.3, n=14)\end{array}$ & $\begin{array}{c}5.4-5.9 \\
(5.7 \pm 0.2, n=4)\end{array}$ & $\begin{array}{c}4.9-5.8 \\
(5.2 \pm 0.3, \mathrm{n}=8)\end{array}$ & $\begin{array}{c}5.2-6 \\
(5.7 \pm 0.3, \mathrm{n}=12)\end{array}$ & $\begin{array}{c}4.4-5.8 \\
(5.1 \pm 0.3, \mathrm{n}=24)\end{array}$ & $\begin{array}{c}4.5-6 \\
(5.2 \pm 0.4, n=24)\end{array}$ \\
\hline $\begin{array}{l}\text { Number of } \\
\text { stridulatory teeth }\end{array}$ & $\begin{array}{c}88-124 \\
(105 \pm 12, \mathrm{n}=16)\end{array}$ & - & $\begin{array}{c}103-128 \\
(112 \pm 9, \mathrm{n}=11)\end{array}$ & - & $\begin{array}{c}91-125 \\
(108 \pm 8.5, \mathrm{n}=11)\end{array}$ & - \\
\hline Ovipositor length & - & $\begin{array}{c}22.2-26.5 \\
(23.6 \pm 1.6, \mathrm{n}=5)\end{array}$ & - & $\begin{array}{c}23.1-29.2 \\
(25.1 \pm 2.0, \mathrm{n}=9)\end{array}$ & - & $\begin{array}{c}26.2-30.2 \\
(28.3 \pm 1.1, \mathrm{n}=18)\end{array}$ \\
\hline
\end{tabular}

\section{Psorodonotus macedonicus Ramme, 1931}

Figs 2B, 3, 4B, 5B, 6B, 7B, 8B, 9, 10, Tables 2, 3

Psorodonotus macedonicus: Ramme, 1931: 184.

Psorodonotus illyricus macedonicus: Mikšić, 1965: 203-213. Psorodonotus fieberi macedonicus: Heller, 1988: 134, 135.

\section{Morphological description}

See the references above; Harz, 1969 (as illyricus macedonicus). Bioacoustics: Heller, 1988; Ingrisch \& Pavićević, 2012 (partim[?] as illyricus illyricus / illyricus macedonicus intermediate form). Karyology: Warchałowska-Śliwa et al., 2005 (as illyricus macedonicus).

General description and diagnosis

Male usually brownish (brownish-violet), females mostly green (rarely are females also brown) (Fig. 2C1, 2). Male pronotal (Fig. 4B1-3) disc is less rugose than in P. fieberi, but similar to that of $P$. illyricus; metazona is strongly widened or sometimes elongated, shovel-like. The metazona is long with a transverse furrow (sulcus) before the middle of the pronotum (rarely at its middle). Female pronotal (Fig. 4B4-6) disc usually with a longer metazona than in $P$. fieberi and a less rugose surface; however, distinction by the female pronotum may be difficult. Male tegmina (Fig. $5 \mathrm{~B} 1,2)$ similar in shape to those of $P$. fieberi or slightly elongated and reaching the third tergite. Male cerci (Fig. 5B3, 4) much longer than those of $P$. illyricus and longer or about the same length as those of $P$. fieberi but the basal part is very short, between over 5 to 6 times shorter than the apical part; base of cerci 2-3 times wider than the apical part; cercal tooth similar in length but narrower than that of $P$. fieberi and shorter than that of $P$. illyricus. Titillator (Fig. 7B) narrower apically bearing one row of teeth (rarely additional small teeth present on its dorsal surface); its basal part similar in length to that of $P$. fieberi but usually thinner, especially medially. Female subgenital plate (Fig. 6B3, 4) is shorter than that of P. fieberi, with wider apical lobes and incision reaching the middle of the sclerite. Ovipositor (Fig. 6B1, 2) varies in curvature and length (23.8-27 mm; Harz, 1969) but on average is longer than that of $P$. fieberi (Table 3); it is usually more slender than that of $P$. fieberi and generally slightly stouter or similar to that of $P$. illyricus. Hind femora in the specimens studied slightly longer than in P. fieberi (mean values) and very similar in length to those of $P$. illyricus, but with greater ratio length: width (Table 3 ).

Song (Fig. 8B) consists of sparsely repeated syllables with a slightly higher repetition rate than recorded for $P$. fieberi $\left(0.4-1 \mathrm{~Hz}\right.$ at $\left.23-28^{\circ} \mathrm{C}\right)$. The main element starts with a compact impulse series and usually ends (especially at low temperatures) with a sparse sequence of impulses, the last of which resemble after-clicks.

\section{Distribution}

Fig. 10, Appendix 2. Occurs throughout the Pindos Mountain Range, mountains of the Pelagonia horst-anticlinorium and southern part of the Dinaric Mountain Range (Greece except Peloponnese, Republic of Macedonia, Albania, W Kosovo, S Montenegro and possibly partly Serbia). The borders with the ranges of $P$. fieberi and especially $P$. illyricus are not clear. The border with the latter possibly passes along the Drina - Tara River Valleys, where contact between populations or a hybrid zone is suspected. The locality in Skopska Crna Gora Mt. (N R Macedonia) belongs to a geographically intermediate region between the Pindo-Dinaric Range and Macedonian-Thracian Massif, but as the specimens from there have not been included in a special study (e.g., by Mikšić, 1965), their taxonomic affinity needs to be confirmed.

This species inhabits open grass-herbaceous plant associations, usually with higher humidity than those inhabited by $P$. fieberi and is even recorded from peat bogs. This species is recorded within the altitudinal range (?1200) 1400-2500 (?2600) $\mathrm{m}$ alt., where it is common between 1500 and $2200 \mathrm{~m}$.

\section{Psorodonotus illyricus Ebner, 1923}

Figs 2C, 3, 4C, 5C, 6C, 7C, 8C, 9, 10, Tables 2, 3

Psorodonotus fieberi illyricus: Ebner, 1923: 250, 251.

Psorodonotus illyricus illyricus: Mikšić, 1965: 203-213.

Psorodonotus fieberi illyricus: Heller, 1988: 134, 135.

Morphological description

See the references above; Ramme, 1931 (as fieberi illyricus); Harz, 1969 (as illyricus illyricus). Bioacoustics: 


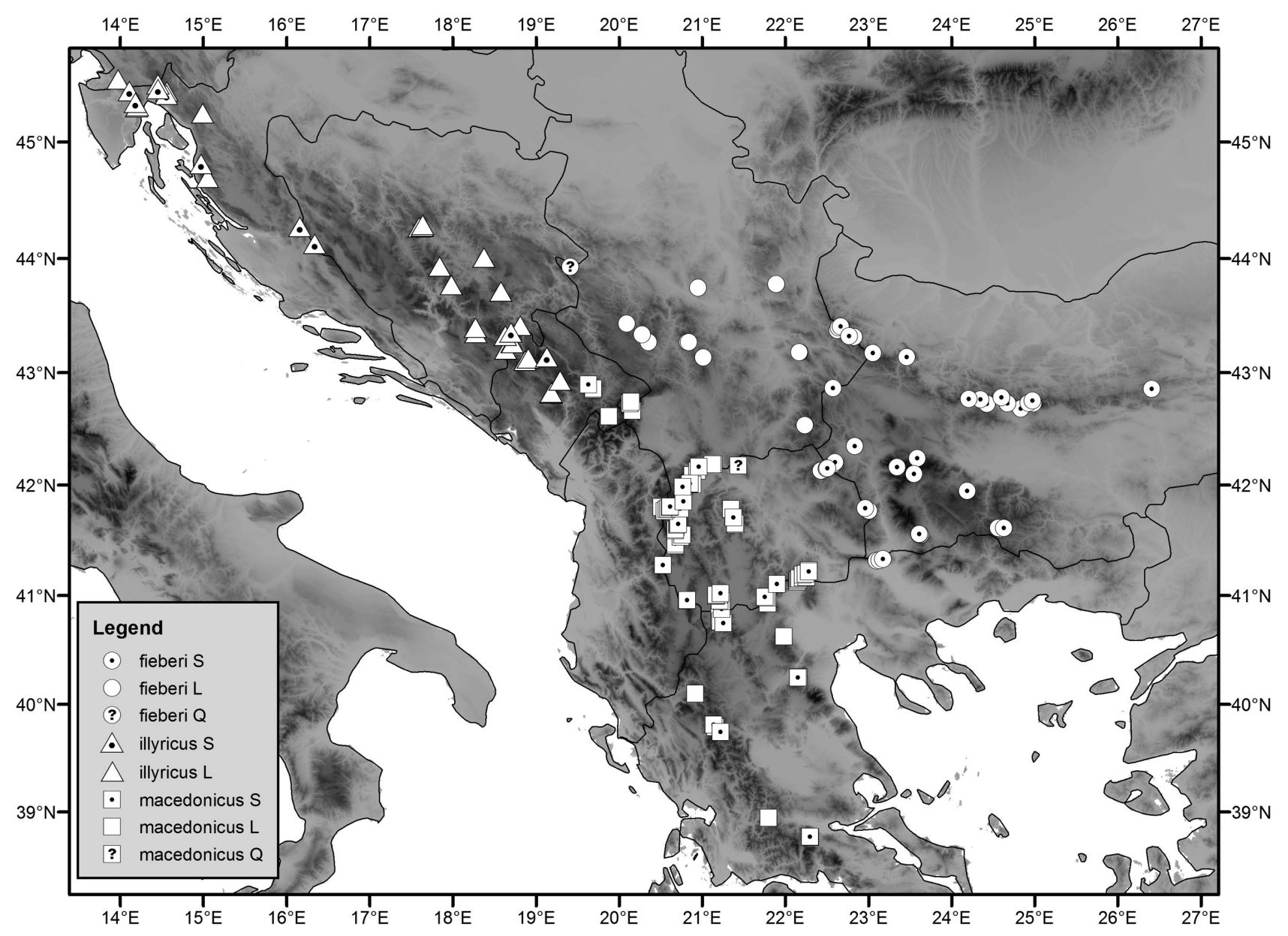

Fig. 10. Map showing the distribution of the genus Psorodonotus in the Balkan Peninsula: circles - P. fieberi, squares - P. macedonicus, triangles - P. illyricus. Open signs - literature data (L), signs with a centered dot - studied material (S), question mark - doubtful identification $(\mathrm{Q})$.

Heller, 1988; Keuper et al., 1988; Weidemann, 1993; Jatho et al., 1994.

\section{General description and diagnosis}

Either a greenish or brownish (brownish-violet) colour seems to be common in this taxon, while in different populations one of these colours may dominate (Fig. 2C1, 2). Male pronotal (Fig. 4C1-3) disc is the least rugose of the three taxa with the metazona sometimes almost smooth. The metazona is notably wider and longer than the prozona if compared to $P$. fieberi, the transverse furrow (if visible) is located before the middle of the pronotum, and the hind pronotal sulcus reaches the median keel well before the middle of the pronotum. Female pronotal (Fig. 4C4-6) disc with notably elongated metazona, very similar to that of $P$. macedonicus. Male tegmina (Fig. 5C1) wider and longer than in the other two taxa and usually covering the third tergite. Male cerci (Fig. 5C2-4) much shorter than in the other two species with a very wide basal part and a long tooth; basal part 2-2.5 (rarely up to 3.5) times shorter than the apical part; base of cerci 3-7 times wider than the apical part. Titillator (Fig. 7C) similar to that of P. macedonicus apically but the arms are usually shorter and wider; its basal arms very wide, much stouter than those of $P$. macedonicus (with some exceptions, e.g., see Fig. 7C2), and very long (longer than in the other taxa). Female subgenital plate (Fig. 6C3-5) resembles that of $P$. macedonicus but the excision may be wider and deeper, exceeding the middle of this sclerite. Ovipositor (Fig. 6C1,2) varies in curvature and length (26-31 mm; Harz, 1969) but is usually more gracile than in $P$. fieberi, elongated and less wide at its base, and on average the longest of the three taxa (Table 3 ). Hind femora in the specimens studied the longest of the three species, with lowest ratio length: width, but the values overlap with the other taxa (Table 3 ).

Song (Fig. 8C) consists of densely repeated syllables (syllables repetition rate highest for these three taxa) (1-3 $\mathrm{Hz}$ at $\left.23-28^{\circ} \mathrm{C}\right)$. The main element is the longest of the taxa studied at a particular temperature and lacks afterclicks (though at low temperatures the last impulses may be separated by longer intervals as in P. macedonicus).

\section{Distribution}

Fig. 10, Appendix 2. Occurs along the Dinaric Mountain Range from Istra Peninsula in S Slovenia and NW Croatia, through Bosnia and Herzegovina to the central regions of Montenegro. It is possibly isolated from populations of P. macedonicus to the South/South-east by the Drina and Tara River Valleys, where it is suspected populations come into contact and there may be a hybrid zone. Ebner (1923) 
records a locality for $P$. illyricus in Bulgaria ("Bulgarien") but this may be the result of wrong label.

This species inhabits open grass/herbaceous plant associations in the colline to subalpine mountain zones. It seems less sensitive to drought and high temperature than the other two taxa. This species is recorded at altitudes between 800 and $1800 \mathrm{~m}$.

ACKNOWLEDGEMENTS. We owe special thanks to M. Ilieva for preparing the distribution map of the Balkan Psorodonotus. Thanks are due also to N. Tvrtković and M. Malenica for their help in collecting material and valuable comments. We acknowledge the comments on the manuscript, the technical and linguistic corrections by two anonymous reviewers, as well as the linguistic review by the language editor. This study was funded by grant KBAG-111T910 by TÜBITAK to B. Çıplak and grant 2011/01/B/ NZ8/01467 from the National Science Centre of Poland to B Grzywacz. The research visit of D. Chobanov to Akdeniz University, which resulted in this joint study, was funded by a postdoctoral research grant awarded by TÜBITAK.

\section{REFERENCES}

AlJanabi S.M. \& Martinez I. 1997: Universal and rapid saltextraction of high quality genomic DNA for PCR-based techniques. - Nucl. Acids Res. 25: 4692-4693.

Allegrucci G., Todisco V. \& SBordoni V. 2005: Molecular phylogeography of Dolichopoda cave crickets (Orthoptera, Rhaphidophoridae): A scenario suggested by mitochondrial DNA. - Mol. Phylog. Evol. 37: 153-164.

Arias A., Márquez R., Llusia D., Beltrán J.F., Slimani T., Radi M., Fattah A. \& El Mouden E.H. 2012: Effects of temperature on the song parameters of the Moroccan bushcricket Eugaster spinulosa (Orthoptera, Tettigoniidae). - Bioacoustics 21: 225-238.

BRUNNER VON WATTENWYL C. 1861: Disquisitiones orthopterologicae. Dissertatio II. Nonnulla Orthoptera europaea nova vel minus cognita. - Verh. Zool.-Bot. Ges. Wien 11: 285-310.

BRUNNER VON WatTenWYL C. 1882: Prodromus der Europaischen Orthopteren. Engelmann, Leipzig, 466 pp.

Çiplak B., Heller K.-G. \& Willemse F. 2009: Review of the genus Eupholidoptera (Orthoptera, Tettigoniidae): different genitalia, uniform song. - Zootaxa 2156: 1-77.

Darriba D., Taboada G.L., Doallo R. \& Posada D. 2012: jModelTest 2: more models, new heuristics and parallel computing. - Nature Meth. 9: 772.

Eades D.C., Otte D., Cigliano M.M. \& Braun H. 2014: Orthoptera Species File. Version 5.0/5.0. Available from: http://Orthoptera.SpeciesFile.org (accessed 16 October 2013).

EBNER R. 1923: Revision der Gattung Psorodonotus (Orthoptera, Phasgonuridae). - Lotos 2: 249-256.

Felsenstein J. 1985: Confidence limits on phylogenies: an approach using the bootstrap. - Evolution 39: 783-791.

FIEBER F.X. 1853: Synopsis der europäischen Orthopteren, mit besonderer Rücksicht auf die in Böhmen vorkommenden Arten. - Lotus (Prague) 3: 90-104, 115-131, 138, 154, 168176, 184-188, 201-207, 232-238, 252-261.

FisCHER VON WALDHEIM G. 1839: Locustarum quaedam genera aptera novo examini submissa. - Bull. Soc. Imp. Nat. Moscou 12(3): 99-114.

FISCHER VON WALDHEIM G. 1846: Entomographia Imperii Rossici. IV. Orthoptera Imperii Rossici. — Nouv. Mém. Soc. Imp. Natur. Moscou 8(3): i-iv, 1-443.

GrebenshChIKOV O. 1950: Contribution to the knowledge of the high mountain fauna of grasshoppers (Orthoptera) in eastern
Yugoslavia. - Sborn. Rad. Inst. Ecol. Sistem. Akad. Nauk. Beograd (B) 1949: 181-195 [in Serbo-Croatian].

Guindon S. \& Gascuel O. 2003: A simple, fast and accurate method to estimate large phylogenies by maximum-likelihood. - Syst. Biol. 52: 696-704.

Harz K. 1969: The Orthoptera of Europe. Vol. 1. Dr. W. Junk, The Hague, 749 pp.

Hebert P.D.N., Cywinska A., Ball S.L. \& de WaArd J.R. 2003: Biological identifications through DNA barcodes. - Proc. $R$. Soc. Lond. (B) 270: 313-321.

HelleR K.-G. 1988: Bioakustik der Europäischen Laubheuschrecken. J. Margraf, Weikersheim, 358 pp.

Heller K.-G. 2006: Song evolution and speciation in bush-crickets. In Drosopolus S. \& Claridges M.F. (eds): Insect Sounds and Communication: Physiology, Behaviour, Ecology and Evolution. Francis and Taylor, New York, pp. 137-153.

Heller K.-G., Orci K.M., Grein G. \& Ingrisch S. 2004: The Isophya species of Central and Western Europe (Orthoptera: Tettigonioidea: Phaneropteridae). — Tijdschr. Entomol. 147: 237-258.

Herman O. 1874: Die Decticiden der Brunner von Wattenwyl'schen Sammlung. - Verh. Zool.-Bot. Ges. Wien 24: 191210.

IngRISCH S. \& PAVIĆEviĆ D. 2012: Faunistics, distribution and stridulation of orthopteroid insects of the Durmitor plateau and the surrounding canyons. - Fauna Balkana (Novi Sad) 1: $13-120$

Jacobson G.G. \& Bianchi V.L. 1905: Orthopteroid and Pseudoneuropteroid Insects of Russian Empire and Adjacent Countries. Devriena, St. Petersburg, 466 pp.

Jatho M., Schul J., Stiedl O. \& Kalmring K. 1994: Specific differences in sound production and pattern recognition in tettigoniids. - Behav. Proc. 31: 293-300.

Kaya K., Korkmaz M. \& ÇiplaK B. 2013: Psorodonotus venosus group (Orthoptera, Tettigoniidae; Tettigoniinae): geometric morphometry revealed two new species in the group. Zootaxa 3750: 37-56.

Kaya S., Chobanov D. \& Çı́lak B. 2014: Review of Psorodonotus specularis group (Orthoptera, Tettigoniidae, Tettigoniinae): two new species from North-east Anatolia. - Zootaxa 3895: 367-400.

Keuper A., Weidemann S., Kalmring K. \& Kaminski D. 1988: Sound production and sound emission in seven species of European Tettigoniids. Part I. The different parameters of the song; their relation to the morphology of the bushcricket. Bioacoustics 1: 31-48.

KLINGENBERG C.P. 2011: MorphoJ: an integrated software package for geometric morphometrics. - Mol. Ecol. Res. 11: 353357.

Librado P. \& Rozas J. 2009: DnaSP v5: A software for comprehensive analysis of DNA polymorphism data. - Bioinformatics 25: 1451-1452.

Martin S.D., Gray D.A. \& Cade W.H. 2000: Fine-scale temperature effects on cricket calling song. - Can. J. Zool. 78: 706-712.

MiKŠIĆ S. 1965: Examen de la valence des formes du genre Psorodonotus Br. W. (Orthoptera) dans la peninsule des Balkans. - Glasn. Zemaljsk. Muz. Sarajevo (N.S.) 3/4: 203-212.

Rambaut A. \& DRummond A.J. 2003: Tracer v1.5. Distributed by the authors available from http://beast.bio.ed.ac.uk/.

Ramme W. 1931: Beiträge zur Kenntnis der palaearktischen Orthopterenfauna (Tettig. et Acrid.). - Mitt. Zool. Mus. Berlin 17: 165-200. 
Ramme W. 1951: Zur Systematik, Faunistik und Biologie der Orthopteren von Südost Europa und Vorderasien. - Mitt. Zool. Mus. Berlin 27: 1-421.

RoHLF F.J. 2002: tpsDig32 v. 1.31. Department of Ecology and Evolution, State University of New York at Stony Brook, Stony Brook, http://life.bio.sunysb.edu/morph/soft-utility.html.

RohLF F.J. 2004: tpsUtil v. 1.26. Department of Ecology and Evolution, State University of New York at Stony Brook, http://life. bio.sunysb.edu/morph/soft-utility.html.

Ronquist F. \& Huelsenbeck J.P. 2003: MrBayes version 3.0: Bayesian phylogenetic inference under mixed models. - Bioinformatics 19: 1572-1574.

Ronquist F., Huelsenbeck J.P. \& van der Mark P. 2005: MrBayes 3.1 Manual. Draft 5/26/2005. Available at http://mrbayes.csit. fsu.edu/manual.php.

Shapiro L.H., Strazanac J.S. \& Roderick G.K. 2006. Molecular phylogeny of Banza (Orthoptera: Tettigoniidae), the endemic katydids of the Hawaiian Archipelago. - Mol. Phylog. Evol. 41: 53-63.

SHAw K.L. 2002: Conflict between nuclear and mitochondrial DNA phylogenies of a recent species radiation: What mtDNA reveals and conceals about modes of speciation on Hawaiian crickets. - PNAS 99: 16122-16127.

Simon C., Frati F., Beckenbach A., Crespi B., Liu H. \& Flook P. 1994: Evolution, weighting, and phylogenetic utility of mitochondrial gene sequences and a compilation of conserved polymerase chain reaction primers. - Ann. Entomol. Soc. Am. 87: 651-702.

Simpson G.G. 1951: The species concept. — Evolution 5: 285298.
Swofford D.L. 2000: PAUP*. Phylogenetic Analysis Using Parsimony (*and Other Methods). Ver. 4. Sinauer Associates, Sunderland, Massachusetts.

Tamura K., Peterson D., Peterson N., Stecher G., Nei M. \& KumAr S. 2011: MEGA5: molecular evolutionary genetics analysis using maximum likelihood, evolutionary distance, and maximum parsimony methods. - Mol. Biol. Evol. 28: 2731-2739.

TaYlan M., Mol A. \& ŞIRIN D. 2014: A new species of Psorodonotus (Orthoptera, Tettigoniidae) from Anatolia, Turkey. Zootaxa 3760: 449-457.

Ullrich B., Reinhold K., Niehius O. \& Misof B. 2010: Secondary structure and phylogenetic analysis of the internal transcribed spacers 1 and 2 of bush crickets (Orthoptera: Tettigoniidae: Barbitistini). - J. Zool. Syst. Evol. Res. 48: 219-228.

ÜnaL M. 2013: Four new species of Tettigoniidae (Orthoptera) from Turkey. - Far Eastern Entomol. 256: 1-16.

WarchalowsKa-Ślima E., Heller K.-G. \& MaryańsKa-NadaCHOWsKa A. 2005: Cytogenetic variability of European Tettigoniinae (Orthoptera, Tettigoniidae): karyotypes, C- and AgNOR-banding. - Folia Biol. (Kraków) 53: 161-171.

WeIDEmann S. 1993: Bioacoustic investigations on the interspecific and interindividual variabilities of stridulatory songs of decticines (Decticus albifrons, Decticus verrucivorus, Psorodonotus illyricus). - Mitt. Dt. Ges. Allgem. Angew. Entomol. 8: 669-674.

Received November 30, 2014; revised and accepted February 4, 2015 Prepublished online March 9, 2015 
APPENDIX 1. Material of Psorodonotus used for geometric morphometrics and/or molecular phylogenetic analysis.

\begin{tabular}{|c|c|c|c|c|c|}
\hline Identification & $\begin{array}{l}\text { Geographic range / } \\
\text { Country }\end{array}$ & $\begin{array}{l}\text { Locality, date, number } \\
\text { of studied specimens }\end{array}$ & $\begin{array}{l}\text { Geographic } \\
\text { position }\end{array}$ & Collector & $\begin{array}{l}\text { Code of haplotypes } \\
\text { used in the analysis }\end{array}$ \\
\hline fieberi & Balkan Mts / Bulgaria & $\begin{array}{c}\text { W Stara Planina Mts, Purshevitsa Lodge, } \\
1350-1450 \mathrm{~m}, 18.09 .2012,1 \delta^{\lambda}\end{array}$ & $\begin{array}{l}43.14249^{\circ} \mathrm{N} \\
23.47067^{\circ} \mathrm{E}\end{array}$ & D. Chobanov & P. fieberi 5 \\
\hline fieberi & Balkan Mts / Bulgaria & $\begin{array}{l}\text { W Stara Planina Mts, Midzhur Peak, } \\
1900 \mathrm{~m}, 9.09 .2012,1{ }^{\lambda}\end{array}$ & $\begin{array}{l}43.40810^{\circ} \mathrm{N} \\
22.66795^{\circ} \mathrm{E}\end{array}$ & D. Chobanov & P. fieberi 6 \\
\hline fieberi & Balkan Mts / Bulgaria & $\begin{array}{l}\text { C Stara Planina Mts, Vezhen Peak, } \\
1600 \mathrm{~m}, 22.09 .2012,1 \delta^{\lambda} \\
\end{array}$ & $\begin{array}{l}42.72646^{\circ} \mathrm{N} \\
24.42808^{\circ} \mathrm{E}\end{array}$ & D. Chobanov & P. fieberi 4 \\
\hline fieberi & Balkan Mts / Bulgaria & $\begin{array}{l}\text { C Stara Planina Mts, Ravnets ridge above } \\
\text { Karlovo, } \sim 1950 \text { m, 25.09.2012, } 1 \hat{\delta}\end{array}$ & $\begin{array}{l}42.681^{\circ} \mathrm{N} \\
24.853^{\circ} \mathrm{E}\end{array}$ & D. Chobanov & - \\
\hline fieberi & Balkan Mts / Bulgaria & $\begin{array}{c}\text { C Stara Planina Mts, Botev Peak, } \\
2150 \mathrm{~m}, 30.09 .2012,1 \delta^{\lambda}\end{array}$ & $\begin{array}{l}42.73094^{\circ} \mathrm{N} \\
24.92817^{\circ} \mathrm{E} \\
\end{array}$ & D. Chobanov & P. fieberi 3 \\
\hline fieberi & $\begin{array}{l}\text { Macedonian-Thracian } \\
\text { Massif / Bulgaria }\end{array}$ & $\begin{array}{c}\text { Belassitsa Mt., Kongur Peak, } 1860 \mathrm{~m}, \\
\text { 12.08.2011, } 11 \hat{\jmath}, 5+q\end{array}$ & $\begin{array}{l}41.32459^{\circ} \mathrm{N} \\
23.17166^{\circ} \mathrm{E}\end{array}$ & D. Chobanov & P. fieberi 1,2 \\
\hline macedonicus & $\begin{array}{l}\text { S Pindo-Dinaric Mt Range } \\
\text { / Greece }\end{array}$ & $\begin{array}{c}\text { Oiti Mt., Ipati Refuge SW Lamia, } \\
1800-1900 \mathrm{~m}, 11 / 13.08 .1973,1 \delta, 1+\end{array}$ & $\begin{array}{c}38.76667^{\circ} \mathrm{N} \\
23.3^{\circ} \mathrm{E} \\
\end{array}$ & F. Willemse & - \\
\hline macedonicus & $\begin{array}{l}\text { S Pindo-Dinaric Mt Range } \\
\text { / Greece }\end{array}$ & $\begin{array}{c}3 \mathrm{~km} \mathrm{~N} \text { of Metsovon [Metsovo], } \\
1400 \mathrm{~m}, \mathrm{~F} \text {. Willemse, } 1 \hat{\jmath}, 19\end{array}$ & $\begin{array}{r}39.79^{\circ} \mathrm{N} \\
21.162^{\circ} \mathrm{E} \\
\end{array}$ & F. Willemse & - \\
\hline macedonicus & $\begin{array}{l}\text { S Pindo-Dinaric Mt Range } \\
\text { / R Macedonia }\end{array}$ & $\begin{array}{c}\text { Jablanica Mt., Strizhek Peak, } \\
\text { 1900-2000 m, 18/19.07.2006, 2ふ઼ }\end{array}$ & $\begin{array}{l}41.28^{\circ} \mathrm{N} \\
20.53^{\circ} \mathrm{E} \\
\end{array}$ & D. Chobanov & P. macedonicus 5 \\
\hline macedonicus & $\begin{array}{l}\text { S Pindo-Dinaric Mt Range } \\
\text { / R Macedonia }\end{array}$ & $\begin{array}{c}\text { Bistra Mt. (Mavrovo NP), } 1800 \mathrm{~m}, \\
\text { 26.07.1969,1 } \delta^{\lambda}, 1+\end{array}$ & - & F. Willemse & - \\
\hline macedonicus & $\begin{array}{l}\text { S Pindo-Dinaric Mt Range } \\
\text { / R Macedonia }\end{array}$ & $\begin{array}{c}\text { Bistra Mt., Tonivoda highland, } \\
1625-1700 \mathrm{~m}, 18.07 .2013,5 \hat{\jmath}, 7 \text { 웅 }\end{array}$ & $\begin{array}{l}41.64383^{\circ} \mathrm{N} \\
20.69788^{\circ} \mathrm{E} \\
\end{array}$ & D. Chobanov 1 & P. macedonicus 3 , \\
\hline macedonicus & $\begin{array}{c}\text { S Pindo-Dinaric Mt Range } \\
\text { / R Macedonia }\end{array}$ & $\begin{array}{l}\text { Korab Mt., Strezimir-Kobilino Pole, } \\
1800-2300 \mathrm{~m}, 16.07 .2013,1 \delta, 2 \text { 웅 }\end{array}$ & $\begin{array}{l}41.79366^{\circ} \mathrm{N} \\
20.59361^{\circ} \mathrm{E}\end{array}$ & D. Chobanov 1 & P. macedonicus 1,2 \\
\hline macedonicus & $\begin{array}{l}\text { N Pindo-Dinaric Mt Range } \\
\text { / Montenegro }\end{array}$ & $\begin{array}{c}\text { Biogradska Gora NP, Virgin Forest } \\
\text { Reserve, } 1730 \mathrm{~m}, 25.07 .2001,1{ }^{\lambda}, 1 \text { ㅇ }\end{array}$ & $\begin{array}{l}42.897^{\circ} \mathrm{N} \\
19.6324^{\circ} \mathrm{E} \\
\end{array}$ & M. Langourov & - \\
\hline illyricus & $\begin{array}{l}\text { N Pindo-Dinaric Mt Range } \\
\text { / Montenegro }\end{array}$ & $\begin{array}{c}\text { Šavnik, Gvozd Peak, } 1440 \mathrm{~m}, \\
2.08 .1963,10^{-}\end{array}$ & $\begin{array}{l}42.9748^{\circ} \mathrm{N} \\
19.1476^{\circ} \mathrm{E} \\
\end{array}$ & F. Willemse & - \\
\hline illyricus & $\begin{array}{c}\text { N Pindo-Dinaric Mountain } \\
\text { Range / Montenegro }\end{array}$ & $\begin{array}{c}\text { Durmitor NP, Žabljak, } 1450 \mathrm{~m}, \\
2.08 .1963,1{ }^{\lambda} \\
\end{array}$ & $\begin{array}{c}43.1357^{\circ} \mathrm{N} \\
19.133^{\circ} \mathrm{E} \\
\end{array}$ & F. Willemse & - \\
\hline illyricus & $\begin{array}{l}\text { N Pindo-Dinaric Mt Range } \\
\text { / Bosnia and Herzegovina }\end{array}$ & $\begin{array}{c}\text { Sutjeska NP, Dragos Sedlo, } 1000 \mathrm{~m} \text {, } \\
\text { 2.08.1963, } 1 q\end{array}$ & $\begin{array}{l}43.353^{\circ} \mathrm{N} \\
18.704^{\circ} \mathrm{E}\end{array}$ & F. Willemse & - \\
\hline illyricus & $\begin{array}{l}\text { N Pindo-Dinaric Mt Range } \\
\text { / Bosnia and Herzegovina }\end{array}$ & $\begin{array}{c}\text { Sutjeska NP, Donje Bare, } 1500 \mathrm{~m}, \\
2.08 .1963,1 \delta^{\lambda}\end{array}$ & $\begin{array}{l}43.322^{\circ} \mathrm{N} \\
18.632^{\circ} \mathrm{E}\end{array}$ & F. Willemse & - \\
\hline illyricus & $\begin{array}{l}\text { N Pindo-Dinaric Mt Range } \\
\text { / Croatia }\end{array}$ & 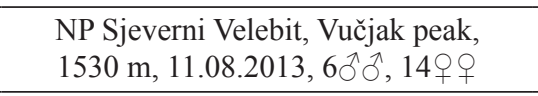 & $\begin{array}{l}44.81175^{\circ} \mathrm{N} \\
14.97403^{\circ} \mathrm{E}\end{array}$ & $\begin{array}{l}\text { J. Skejo, N. } \\
\text { Tvrtković }\end{array}$ & P. illyricus 3,4 \\
\hline illyricus & $\begin{array}{l}\text { N Pindo-Dinaric Mt Range } \\
\text { / Croatia }\end{array}$ & $\begin{array}{c}\text { Poštak Mt., Ljubina Poljana, } 1050 \mathrm{~m} \text {, } \\
\text { 17.08.2013, } 6 \hat{\bigcirc} \widehat{C}\end{array}$ & $\begin{array}{l}44.27246^{\circ} \mathrm{N} \\
16.15848^{\circ} \mathrm{E}\end{array}$ & $\begin{array}{l}\text { N. Tvrtković, } \\
\text { M. Malenica }\end{array}$ & P. illyricus 1,2 \\
\hline illyricus & $\begin{array}{c}\text { N Pindo-Dinaric Mountain } \\
\text { Range / Croatia }\end{array}$ & $\begin{array}{c}\text { Istra Peninsula, Ućka Mt., } 700-1000 \mathrm{~m}, \\
15 / 16.08 .1972,10^{\lambda}\end{array}$ & $\begin{array}{l}45.306^{\circ} \mathrm{N} \\
14.2045^{\circ} \mathrm{E} \\
\end{array}$ & F. Willemse & - \\
\hline caucasicus & Pontic Mountains / Turkey & $\begin{array}{c}\text { Erzurum Prov., Tortum-Oltu, Yayla Pass, } \\
2284 \mathrm{~m}, 3.08 .2012,2 \delta^{\lambda}\end{array}$ & $\begin{array}{l}40.44426^{\circ} \mathrm{N} \\
41.62466^{\circ} \mathrm{E} \\
\end{array}$ & $\begin{array}{l}\text { B. Çıplak, S. } \\
\text { Kaya }\end{array}$ & P. caucasiscus 1,2 \\
\hline venosus & Lesser Caucasus / Turkey & $\begin{array}{c}\text { Ardahan Prov., Çıldır, } 1940 \mathrm{~m}, \\
\text { 4.08.2012, } 1 \delta^{\lambda}\end{array}$ & $\begin{array}{l}41.12459^{\circ} \mathrm{N} \\
421.90636^{\circ} \mathrm{E}\end{array}$ & $\begin{array}{l}\text { B. Çıplak, S. } \\
\text { Kaya }\end{array}$ & P. venosus \\
\hline specularis & Lesser Caucasus / Turkey & $\begin{array}{c}\text { Ardahan Prov., Çıldır, } 1940 \mathrm{~m}, \\
4.08 .2012,1 \hat{\sigma}^{\lambda}\end{array}$ & $\begin{array}{l}41.12459^{\circ} \mathrm{N} \\
421.90636^{\circ} \mathrm{E}\end{array}$ & $\begin{array}{l}\text { B. Çıplak, S. } \\
\text { Kaya }\end{array}$ & P. specularis \\
\hline
\end{tabular}

APPEndix 2. Locality list of the Balkan Psorodonotus from literature and unpublished data.

In the following list we present all published and unpublished localities of the Balkan Psorodonotus known to us. Data are arranged into respective taxonomic units after critical review. Doubtful records are shortly commented or related to "Incertae sedis". The localities that were traceable are geographically ref- erenced using decimal coordinates according to appropriate location and habitat and mapped (Fig. 10 in the text). The localities are arranged mostly in a north-south direction. For published data usually only original references (i.e. such reporting unpublished before information or treating the taxon in a different sense) are used given in brackets. Question marks indicate uncertainty about the respective information. 


\section{Abbreviations (others than widely used):}

$\mathrm{AU}$ - Zoological Collection of the Faculty of Science of Akdeniz University; $\mathrm{CC}$ - Collectio Chobanov; $\mathrm{CH}$ - Collectio Heller; DC - D. Chobanov leg.; EA - E. Andreeva leg.; HMB - Historical Museum in Blagoevgrad, Bulgaria; JS - Josip Skejo leg. or obs. (nymphal stage); MM - Marta Malenica leg.; GP - Georgi Peshev leg.; MMNH - Macedonian Museum of Natural History, Skopje; SOFM - National Museum of Natural History, Sofia; NT - Nikola Tvrtković leg.

\section{Psorodonotus fieberi (Fieber, 1853)}

"Rumelien" [either Bulgaria or Serbia] (Fryvaldsky [Frydvaldsky] in Fieber, 1853 as Pterolepis fieberi); "Bulgarien" (Ebner, 1923 as $P$. fieberi illyricus [wrong label or identification!]).

Bulgaria (all citations as $P$. fieberi unless specified): Stara Planina Mts: Midzhur Peak, $1900-2000 \mathrm{~m}\left(43.40810^{\circ} \mathrm{N}, 22.66795^{\circ} \mathrm{E}\right)$, DC, CC; Kom Peak, $2015 \mathrm{~m}\left(43.1731^{\circ} \mathrm{N}, 23.0562^{\circ} \mathrm{E}\right)(\mathrm{Pe}-$ shev, 1970); Vrachanksa Planina, Purshevitsa Chalet, $1400 \mathrm{~m}$ $\left(43.1399^{\circ} \mathrm{N}, 23.4631^{\circ} \mathrm{E}\right), \mathrm{DC}, \mathrm{CC}$; Paskal Peak $\left(42.7687^{\circ} \mathrm{N}\right.$, $\left.24.2082^{\circ} \mathrm{E}\right)$, M. Vitanova leg., SOFM; Vezhen Peak, $1600 \mathrm{~m}$ $\left(42.72646^{\circ} \mathrm{N}, 24.42808^{\circ} \mathrm{E}\right), \mathrm{DC}, \mathrm{CC}$; Benkovski Chalet, $1800 \mathrm{~m}$ $\left(42.7648^{\circ} \mathrm{N}, 24.3522^{\circ} \mathrm{E}\right)($ Peshev, 1974b); "Central Balkan” N.P., 1400-1800 m (e.g., $42.681^{\circ} \mathrm{N}, 24.834^{\circ} \mathrm{E}$ ) (Drenowski, 1929; Buresch \& Peschev, 1958); Troyanski Prohod Pass, 1400-1500 m $\left(42.782^{\circ} \mathrm{N}, 24.603^{\circ} \mathrm{E}\right)$ (Bey-Bienko \& Peshev, 1960); Dermenkaya Chalet $\left(42.728^{\circ} \mathrm{N}, 24.675^{\circ} \mathrm{E}\right)$ (Peshev, 1974b); Ravnets Ridge, $1950 \mathrm{~m}\left(42.681^{\circ} \mathrm{N}, 24.853^{\circ} \mathrm{E}\right), \mathrm{DC}, \mathrm{CC}$; Botev Peak, 1800-2000 m (e.g., $\left.42.7272^{\circ} \mathrm{N}, 24.984^{\circ} \mathrm{E}\right)$ (Peshev, 1974b) \& $2150 \mathrm{~m}\left(42.73094^{\circ} \mathrm{N}, 24.92817^{\circ} \mathrm{E}\right), \mathrm{DC}, \mathrm{CC}$; Tazha Chalet, 1700 m $\left(42.7534^{\circ} \mathrm{N}, 24.9775^{\circ} \mathrm{E}\right), \mathrm{GP}, \mathrm{SOFM}$; "Stara Planina, Sliven Region" (Nedelkov, 1908); Razboyna Peak, 1128 m (42.8586 N, $26.4134^{\circ} \mathrm{E}$ ) (Peshev, 1974b wrongly as "Kotel surroundings, 600 m"; data corrected with material in SOFM); Ruy Mt.: Ruy Peak, 1600-1700 m $\left(42.8638^{\circ} \mathrm{N}, 22.5768^{\circ} \mathrm{E}\right), \mathrm{DC}, \mathrm{CC}$; Konyavska Planina Mt.: above Konyavo Vill. $\left(42.3492^{\circ} \mathrm{N}, 22.8369^{\circ} \mathrm{E}\right), \mathrm{EA}$ HMB; Ossogovska Planina Mts: "1500-2253 m" (Drenowski 1927 as Psorodonotus (Podisma) fieberi Scudd.; possibly printing error due to the same species name); Ruen Peak slopes, 1800 $2200 \mathrm{~m}\left(42.1634^{\circ} \mathrm{N}, 22.533^{\circ} \mathrm{E} ; 42.1676^{\circ} \mathrm{N}, 22.541^{\circ} \mathrm{E}\right), \mathrm{DC}, \mathrm{CC}$; $1 \mathrm{~km} \mathrm{SW}$ Begbunar Place, $1850 \mathrm{~m}\left(42.1871^{\circ} \mathrm{N}, 22.5792^{\circ} \mathrm{E}\right)$, DC, CC; Kyunek - Choveka Peaks, 1900-1950 m (42.2049º N, $\left.22.5991^{\circ} \mathrm{E}\right)$, DC observed; Maleshevska Planina Mts: Ilyov Vruh Peak, $1800 \mathrm{~m}\left(41.7691^{\circ} \mathrm{N}, 23.0086^{\circ} \mathrm{E}\right), \mathrm{DC}, \mathrm{CC}$; Vlakhina Mts: "1500-2000 m" (Peshev \& Andreeva, 1986); Kadiytsa Peak, "1700-2000 m" $\left(41.7914^{\circ} \mathrm{N}, 22.9646^{\circ} \mathrm{E}\right), \mathrm{EA}, \mathrm{HMB}$; Belassitsa Mt.: "1600-2000 m” (Peshev 1962); Kongur - Radomir Peaks - Demir Kapiya Pass, $1700-1900$ m $\left(41.3330^{\circ} \mathrm{N}, 23.1767^{\circ} \mathrm{E}\right.$; $\left.41.3211^{\circ} \mathrm{N}, 23.1351^{\circ} \mathrm{E} ; 41.3192^{\circ} \mathrm{N}, 23.0982^{\circ} \mathrm{E}\right), \mathrm{DC}, \mathrm{CC}$; “above Petrich", $1600 \mathrm{~m} \& 1700 \mathrm{~m} \& 1800 \mathrm{~m}$, GP, HMB; Rila Mts: Elenin Vrukh Peak (e.g., $\left.42.1601^{\circ} \mathrm{N}, 23.3481^{\circ} \mathrm{E}\right)$ (Frey-Gessner, 1893); Borovets Resort, $1250 \mathrm{~m} \& 1450 \mathrm{~m}$ (localities maybe partly extinct) (Buresch \& Peshev, 1958) \& to $2200 \mathrm{~m}\left(42.2400^{\circ} \mathrm{N}\right.$, $\left.23.5900^{\circ} \mathrm{E}\right)($ Peshev, 1990); Pirin Mts: Orelek Peak, $1500-2000$ $\mathrm{m}\left(41.5538^{\circ} \mathrm{N}, 23.6300^{\circ} \mathrm{E} ; 41.5548^{\circ} \mathrm{N}, 23.6130^{\circ} \mathrm{E} ; 41.5613^{\circ} \mathrm{N}\right.$ $\left.23.6151^{\circ} \mathrm{E}\right), \mathrm{DC}, \mathrm{CC} \& 1800-2050 \mathrm{~m}$ (Peshev \& Andreeva, 1986); W Rhodope Mts: "Rodopi" (Nedelkov, 1908; Buresch \& Peschev, 1958); Batak Lake $\left(41.9465^{\circ} \mathrm{N}, 24.1910^{\circ} \mathrm{E}\right)(\mathrm{Chobanov}$, 2012 as P. f. fieberi); Perelik Peak, $1700-2180 \mathrm{~m}\left(41.615^{\circ} \mathrm{N}\right.$, $\left.24.634^{\circ} \mathrm{E} ; 41.6072^{\circ} \mathrm{N}, 24.5784^{\circ} \mathrm{E}\right)($ Peshev, 1975$)$; Shiroka Laka Vill. (e.g., above the village, $41.613^{\circ} \mathrm{N}, 24.562^{\circ} \mathrm{E}$ ) (Chobanov, 2012 as P.f. fieberi); Smolyan (not localized) (Chobanov, 2012 as P. f. fieberi); Stoykite Vill. (not localized) (Peshev, 1974a, 1975); "above Assenovgrad" (not localized) (Nedelkov, 1908).

Serbia: "alpibus Serbiae" (Brunner von Wattenwyl, 1861 as $P$. pancici); Rtanj Mt. (Brunner von Wattenwyl, 1861, 1882; Ebner, 1923 as P.f. fieberi): $1500 \mathrm{~m}\left(43.7769^{\circ} \mathrm{N}, 21.8922^{\circ} \mathrm{E}\right)($ Grebenshchikov, 1950; Mikšić, 1965); Stara Planina Mts: "Stara Planina",
1600-2100 m (Grebenshchikov, 1950); Krive [uclear locality position] (Mikšić, 1965); Žarkov Breg [uclear locality position] (Mikšić, 1965); Midžor - Trapanar [uclear locality position] (Mikšić, 1965); Midžor Peak $\left(43.3957^{\circ} \mathrm{N}, 22.674^{\circ} \mathrm{E}\right)$ (Mikšić, 1965); Babin Zub $\left(43.3765^{\circ} \mathrm{N}, 22.6275^{\circ} \mathrm{E}\right)$ (Mikšić, 1965); Tri Čuke Peak $\left(43.317^{\circ} \mathrm{N}, 22.827^{\circ} \mathrm{E}\right)$ (Mikšić, 1965); Zlatibor (possibly Ilatibor in E Serbia) [comment based on data by Chobanov et al., 2013] (Grebenshchikov, 1950 after Pančić, 1899); Suha (Suva) Planina Mt.: $1750 \mathrm{~m}\left(43.1811^{\circ} \mathrm{N}, 22.1741^{\circ} \mathrm{E}\right)$ (Brunner von Wattenwyl, 1861, 1882; Ebner, 1923 as P. f. fieberi; Grebenshchikov, 1950; Mikšić, 1965); "Suva Planina Mt., Mt. Julio" [uclear locality position] (Grebenshchikov, 1950; Mikšić 1965); Besna Kobila Mt. $\left(42.5344^{\circ} \mathrm{N}, 22.235^{\circ} \mathrm{E}\right)$ (Mikšić, 1965); Ječmenište [Peak in Gledićka Planina Mt. in Serbia; if mountain in Bosnia and Herzegovina, then not P. fieberi!] $\left(43.747^{\circ} \mathrm{N}, 20.953^{\circ} \mathrm{E}\right)$ (Mikšić, 1965); Užice [possibly Javor Mt.] (Mikšić, 1965); Javor Mt. ("M. Javor-Uzica”) (43.431 $\left.{ }^{\circ} \mathrm{N}, 20.091^{\circ} \mathrm{E}\right)$ (Grebenshchikov, 1950 after Pančić, 1899; Ebner 1923 as P. f. fieberi); Golija Mt.: Vrbena [unclear locality position] (Mikšić, 1965); Jankov kamen $\left(43.336^{\circ} \mathrm{N}, 20.277^{\circ} \mathrm{E}\right)($ Mikšić, 1965$) ; 1500-1800 \mathrm{~m}\left(43.271^{\circ} \mathrm{N}\right.$, $\left.20.357^{\circ} \mathrm{E}\right)($ Grebenshchikov, 1950); Kopaonik Mt., 1700-2000 $\mathrm{m}\left(43.269^{\circ} \mathrm{N}, 20.825^{\circ} \mathrm{E}\right)$ (Grebenshchikov, 1950 after Pančić, 1899); Treska [Peak of Kopaonik Mt.] $\left(43.136^{\circ} \mathrm{N}, 21.016^{\circ} \mathrm{E}\right)$ (Mikšić, 1965); Tara Mt. [?P. fieberi] $\left(43.93^{\circ} \mathrm{N}, 19.4125^{\circ} \mathrm{E}\right)(\mathrm{Gre}-$ benshchikov, 1950; Mikšić, 1965).

R Macedonia: Ossogovska Plaina Mts: Ruen ridge, 2000 $\mathrm{m}\left(42.1522^{\circ} \mathrm{N}, 22.5091^{\circ} \mathrm{E}\right)$, DC observed; Ruen peak slopes (Chashka-Ruen), $1800-2200 \mathrm{~m}\left(42.1483^{\circ} \mathrm{N}, 22.4983^{\circ} \mathrm{E}\right), \mathrm{DC}$, CC; Babina Cheshma-Tsarev Vrukh, 1750-2085 m (42.1304 N, $\left.22.4301^{\circ} \mathrm{E} \& 42.1302^{\circ} \mathrm{N}, 22.4517^{\circ} \mathrm{E}\right)$, DC observed.

\section{Psorodonotus illyricus Ebner, 1923}

Slovenia (citations as P. illyricus unless specified): Slavnik $\left(45.5348^{\circ} \mathrm{N}, 13.9726^{\circ} \mathrm{E}\right)(\mathrm{Us}, 1992)$.

Croatia: Istra (Jacobson \& Bianchi, 1905 as P. fieberi; Mikšić, 1965 as P. i. illyricus); Mountains near Rijeka (Weidemann 1993); Senj [possibly a locality in the mountains nearby] (Mikšić, 1965 as P. i. illyricus); Obruč Mt.: Trstenik, $1000 \mathrm{~m}$ $\left(45.49^{\circ} \mathrm{N}, 14.455^{\circ} \mathrm{E}\right)$, photographed by J. Topić; Obruč Mt., W slopes, $800 \mathrm{~m}\left(45.45167^{\circ} \mathrm{N}, 14.455^{\circ} \mathrm{E}\right)$, NT; Ćićarija Mt., Dol, $890 \mathrm{~m}\left(45.43414^{\circ} \mathrm{N}, 14.1122^{\circ} \mathrm{E}\right)$, JS \& NT; Platak [Risnjak Mt.] $\left(45.435^{\circ} \mathrm{N}, 14.559^{\circ} \mathrm{E}\right)$ (Nadig, 1987); E of Rijeka, Kamenjak hill $\left(45.403^{\circ} \mathrm{N}, 14.5545^{\circ} \mathrm{E}\right)$ (Heller, 1988 as P. fieberi illyricus); Vela Učka, Mt. Maggiore (Istrien) $\left(45.3^{\circ} \mathrm{N}, 14.197^{\circ} \mathrm{E}\right)$ (Redtenbacher, 1900 as P. fieberi; Ebner, 1923 as P. fieberi illyricus); Učka Mt., $750-1100 \mathrm{~m}\left(45.306^{\circ} \mathrm{N}, 14.2045^{\circ} \mathrm{E}\right)$, JS; Istra, $15 \mathrm{~km} \mathrm{NE}$ Opatija (Učka Mt.) $\left(45.3356^{\circ} \mathrm{N}, 14.184^{\circ} \mathrm{E}\right)$ (Heller, 1988 as $P$. fieberi illyricus); Vel. Kapela, Brezje-Modruš (com. Fiume-Modrus) $\left(45.249^{\circ} \mathrm{N}, 14.99^{\circ} \mathrm{E}\right)$ (Pungur, 1899); Velebit Mt., Vučjak - Kapelica sv. Ante, $1530-1560 \mathrm{~m}\left(44.81175^{\circ} \mathrm{N}, 14.974^{\circ} \mathrm{E}\right)$, JS \& NT; Velebit Mt., Štirovaca $\left(44.6985^{\circ} \mathrm{N}, 15.0521^{\circ} \mathrm{E}\right)$ (Ebner, 1923 as P. fieberi illyricus); Poštak Mt.: Ljubina Poljana, $1080 \mathrm{~m}$ $\left(44.27246^{\circ} \mathrm{N}, 16.1585^{\circ} \mathrm{E}\right)$, JS, NT \& MM.

Bosnia and Herzegovina: Ivan pl. [unclear locality position] (Grebenshchikov, 1950 as P. fieberi; Mikšić, 1965 as P. i. illyricus); Paljenik Peak [Vlašić Mt.] $\left(44.293^{\circ} \mathrm{N}, 17.638^{\circ} \mathrm{E}\right)$ (Mikšić, 1965 as P. i. illyricus); Galica [hut in Vlašić Mt.] $\left(44.2729^{\circ} \mathrm{N}\right.$, $17.5945^{\circ} \mathrm{E}$ ) (Mikšić, 1965 as P. i. illyricus); Devečani [summit/ chalet in Vlašić Mt.] $\left(44.2752^{\circ} \mathrm{N}, 17.6329^{\circ} \mathrm{E}\right)$ (Mikšić, 1965 as P. i. illyricus); Vlašić Mt. \& Vlašić - Puhalovica - Devečani, $1780 \mathrm{~m}\left(44.2784^{\circ} \mathrm{N}, 17.636^{\circ} \mathrm{E}\right)$ (Mikšić, 1965 as P. i. illyricus); Paklarevo [in the foothills of Vlašić Mt.; unclear locality position] (Mikšić, 1965 as P. i. illyricus); Dinara Mt. (Mikšić, 1965 as P. i. illyricus); Dinara Mt., Risovac (BiH) near Brezovac (HR) $\left(44.1243^{\circ} \mathrm{N}, 16.3392^{\circ} \mathrm{E}\right)$, leg. Müller, Trieste Natural History Museum; Čemerno [pass] $\left(44.0099^{\circ} \mathrm{N}, 18.3788^{\circ} \mathrm{E}\right)($ Ebner, 1923 as P.f. fieberi); Vranica Mt., Matorac, $1500-1800 \mathrm{~m}\left(43.933^{\circ} \mathrm{N}\right.$, 
$\left.17.845^{\circ} \mathrm{E}\right)$ (Ebner, 1923, "Nordabhang des Matorać (Bosnien)", as P. fieberi illyricus; Mikšić, 1965 as P. i. illyricus); Lisin (oder Lim; Herzegowina) $\left(43.7702^{\circ} \mathrm{N}, 17.9832^{\circ} \mathrm{E}\right)$ (Ebner, 1923 as $P$. fieberi illyricus; Mikšić, 1965 as P. i. illyricus); Jahorina Mt., $1800 \mathrm{~m}\left(43.715^{\circ} \mathrm{N}, 18.581^{\circ} \mathrm{E}\right)$ (Grebenshchikov, 1950 as $P$. fieberi; Mikšić, 1965 as P. i. illyricus); Foča (SE Bosnia) [possibly Pljieš Mt.] $\left(43.415^{\circ} \mathrm{N}, 18.815^{\circ} \mathrm{E}\right)$ (Ebner, 1923 as P. fieberi illyricus); Ulog [Jakomir Ridge] $\left(43.3956^{\circ} \mathrm{N}, 18.2729^{\circ} \mathrm{E}\right)$ (Grebenshchikov, 1950 as P. fieberi); Morine [Jakomir Ridge] $\left(43.3498^{\circ} \mathrm{N}\right.$, $18.278^{\circ} \mathrm{E}$ ) (Mikšić, 1965 as P. i. illyricus); Zelengora Mt., Sutjeska NP, Donje Bare Lake, $1500 \mathrm{~m}\left(43.322^{\circ} \mathrm{N}, 18.632^{\circ} \mathrm{E}\right)$, F. Willemse, AU; Zelengora Mt., Sutjeska NP, Dragos Sedlo, $1000 \mathrm{~m}\left(43.353^{\circ} \mathrm{N}, 18.704^{\circ} \mathrm{E}\right), \mathrm{F}$. Willemse, AU; Volujak (Herzegowina) (Ebner, 1923 as P. fieberi illyricus; Grebenshchikov, 1950 as $P$. fieberi); Volujak Mt., Suha jezerina [in Montenegro?] $\left(43.2668^{\circ} \mathrm{N}, 18.7179^{\circ} \mathrm{E}\right.$ ) (Mikšić, 1965 as $P$. i. illyricus); Lebršnik Mt. (43.207 $\left.{ }^{\circ} \mathrm{N}, 18.639^{\circ} \mathrm{E}\right)$ (Mikšić, 1965 as P. i. illyricus);

Montenegro: Sinjajevina - Ljutovac $\left(42.934^{\circ} \mathrm{N}, 19.292^{\circ} \mathrm{E}\right)$ (Mikšić, 1965 as P. illyricus illyricus/macedonicus intermediate form); Lokvice - Bare - Žurim [near Zurim Peak?] (42.8195 N, $19.1859^{\circ} \mathrm{E}$ ) (Mikšić, 1965 as P. illyricus illyricus/macedonicus intermediate form); Durmitor (Grebenshchikov, 1950 as P. fieberi); Durmitor N.P., Žabljak, $1450 \mathrm{~m}\left(43.1357^{\circ} \mathrm{N}, 19.133^{\circ} \mathrm{E}\right)$ (Mikšić, 1965; Ingrisch \& Pavićević, 2012; both as P. illyricus illyricus/macedonicus transitional form), F. Willemse, AU; Jarčište $\left(43.1285^{\circ} \mathrm{N}, 18.909^{\circ} \mathrm{E}\right)$ (Ingrisch \& Pavićević, 2012 as P. illyricus illyricus/macedonicus intermediate form); Borkovići $\left(43.106^{\circ} \mathrm{N}\right.$, $18.8725^{\circ} \mathrm{E}$ ) (Ingrisch \& Pavićević, 2012 as P. illyricus illyricus/ macedonicus transitional form).

\section{Psorodonotus macedonicus Ramme, 1931}

Montenegro: "Belasica" [Bjelasica Mt.] $\left(42.8535^{\circ} \mathrm{N}\right.$, $19.6856^{\circ} \mathrm{E}$ ) (Mikšić, 1965 as P. illyricus illyricus/macedonicus transitional form); Bjelasica Mt., N.P. Biogradksa Gora, $1730 \mathrm{~m}$ $\left(42.897^{\circ} \mathrm{N}, 19.6324^{\circ} \mathrm{E}\right), \mathrm{M}$. Langourov, AU; Visitor Mt., Murino vill. ("Visitor - Murina") $\left(42.614^{\circ} \mathrm{N}, 19.88^{\circ} \mathrm{E}\right)$ (Grebenshchikov, 1950 as P. fieberi; Mikšić, 1965 as P. illyricus macedonicus).

Kosovo (citations as P. illyricus unless specified): Hajla Mt., Pepici $\left(42.7276^{\circ} \mathrm{N}, 20.1303^{\circ} \mathrm{E}\right)$ (Mikšić, 1965 as Albania, as $P$. illyricus macedonicus); Koprivnik Mt., $1800-2000 \mathrm{~m}\left(42.664^{\circ} \mathrm{N}\right.$, $\left.20.16^{\circ} \mathrm{E}\right)$ (Grebenshchikov, 1950 as $P$. fieberi; Mikšić 1965 as $P$. fieberi citing Grebenshchikov, 1950); E ö Prizren (Prevalac Paß) $\left(42.166^{\circ} \mathrm{N}, 20.963^{\circ} \mathrm{E}\right)$ (Heller, 1988 as P. fieberi illyricus); Shar Mts, 2000-2600 m [unclear locality position] (Grebenshchikov, 1950 as P. fieberi).

Albania: Korab Mt. (e.g., $\left.41.8026^{\circ} \mathrm{N}, 20.5093^{\circ} \mathrm{E}\right)$ (Ebner, 1923 as $P$. f. fieberi but noted the female is similar to P. f. illyricus).

R Macedonia: Skopska Crna Gora Mt.: Ramno peak $\left(42.1742^{\circ} \mathrm{N}, 21.4369^{\circ} \mathrm{E}\right)$ (Karaman, 1975) [P. macedonicus?]; Jakupica Mt. (Dimovski, 1968): Goleshnitsa Ridge - near Pepelak (41.784 N, 21.3514º) (Ramme 1951; Mikšić 1965 as P. illyricus macedonicus); the subalpine zone, 1750-2130 $\mathrm{m}\left(41.7098^{\circ} \mathrm{N}, 21.3789^{\circ} \mathrm{E}\right), \mathrm{DC}, \mathrm{CC}$; Cheples chalet - Plavnik place, $1500-1750 \mathrm{~m}\left(41.6531^{\circ} \mathrm{N}, 21.3976^{\circ} \mathrm{E} \& 41.647^{\circ} \mathrm{N}\right.$, $21.4085^{\circ} \mathrm{E}$ ), DC, CC; Shar Mts (Grebenshchikov, 1950 as $P$. fieberi; Harz 1969 as P. illyricus macedonicus): Ljuboten peak $\left(42.185^{\circ} \mathrm{N}, 21.1388^{\circ} \mathrm{E}\right)(\mathrm{Us}, 1938$ as $P$. fieberi; Grebenshchikov 1950 as P. fieberi; Mikšić, 1965 as P. illyricus macedonicus); Crni Vrv $\left(42.128^{\circ} \mathrm{N}, 20.942^{\circ} \mathrm{E}\right)$ (Ramme, 1951); Kobiliza (Kobilica) Peak $\left(42.0739^{\circ} \mathrm{N}, 20.8816^{\circ} \mathrm{E}\right)$ (Ramme, 1951); Cerepašina [Ceripashina], $1700-2500 \mathrm{~m}$ (e.g., $42.0045^{\circ} \mathrm{N}, 20.8868^{\circ} \mathrm{E}$ ) (Mikšić, 1965 as P. illyricus macedonicus; Chobanov \& Mihajlova, 2010 as P. fieberi); Popova Shapka near Tetovo $\left(41.98333^{\circ} \mathrm{N}\right.$, $\left.20.7667^{\circ} \mathrm{E}\right)$, K.-G. Heller \& M. Volleth, CH; Budimov grob Mengulova kula, $2100-2200 \mathrm{~m}\left(41.8533^{\circ} \mathrm{N}, 20.7771^{\circ} \mathrm{E}\right)$, L. Stefanov leg. et coll.; Nichpurska Planina, under Lera Peak, 1900

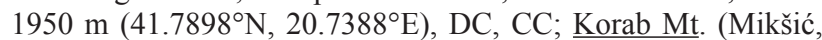

1965 as P. illyricus macedonicus): Strezimir Chalet, 1470 \& 1620 $\mathrm{m}\left(41.80609^{\circ} \mathrm{N}, 20.6186^{\circ} \mathrm{E} \& 41.8016^{\circ} \mathrm{N}, 20.6113^{\circ} \mathrm{E}\right), \mathrm{DC}, \mathrm{AU}$; Kobilino Pole highland, $2250 \mathrm{~m}\left(41.7822^{\circ} \mathrm{N}, 20.5711^{\circ} \mathrm{E}\right), \mathrm{DC}$, AU; Dlaboka Reka Valley, $1850 \mathrm{~m}\left(41.767^{\circ} \mathrm{N}, 20.551^{\circ} \mathrm{E}\right), \mathrm{DC}$, CC; Bistra Mt. (Grebenshchikov, 1950 as P. fieberi): Trebiski ćuk [not localised] (Mikšić, 1965 as P. illyricus macedonicus); E of Zhirovnitsa vill. $\left(41.65^{\circ} \mathrm{N}, 20.716^{\circ} \mathrm{E}\right)$ (Heller, 1988 as P. fieberi illyricus); Mavrovo - Carevec pass (Chobanov \& Mihajlova, 2010 as P. fieberi); Carevec Place - Tonivoda highland, 1625$1700 \mathrm{~m}\left(41.64899^{\circ} \mathrm{N}, 20.7095^{\circ} \mathrm{E} \& 41.64383^{\circ} \mathrm{N}, 20.6979^{\circ} \mathrm{E}\right)$, $\mathrm{DC}, \mathrm{AU}$; Galičnik vill. $\left(41.59^{\circ} \mathrm{N}, 20.673^{\circ} \mathrm{E}\right)$ (Mikšić, 1965 as P. illyricus macedonicus); above Lazaropole vill., 1450-1800 m $\left(41.535^{\circ} \mathrm{N}, 20.7456^{\circ} \mathrm{E} \& 41.5509^{\circ} \mathrm{N}, 20.7622^{\circ} \mathrm{E}\right), \mathrm{DC}, \mathrm{CC}$; Stogovo Mt. (e.g., $\left.41.4583^{\circ} \mathrm{N}, 20.6818^{\circ} \mathrm{E} \& 41.4736^{\circ} \mathrm{N}, 20.6779^{\circ} \mathrm{E}\right)$ (Chobanov \& Mihajlova, 2010); Jablanica Mt.: Strizhek Peak, 1900-2000 m $\left(41.28^{\circ} \mathrm{N}, 20.53^{\circ} \mathrm{E}\right), \mathrm{DC}, \mathrm{CC}$; Galichitsa Mt.: Oteshevo-Ohrid, $1600-1700 \mathrm{~m}\left(40.9552^{\circ} \mathrm{N}, 20.816^{\circ} \mathrm{E}\right), \mathrm{DC}, \mathrm{CC}$ \& L. Stefanov, L. Stefanov coll.; Nidzhe Mt.: Redir place, 1600 $\mathrm{m}\left(40.9908^{\circ} \mathrm{N}, 21.7564^{\circ} \mathrm{E}\right)$, B. Micevski; under Kaymakchalan Peak, $1500-1900 \mathrm{~m}\left(40.9814^{\circ} \mathrm{N}, 21.7893^{\circ} \mathrm{E}\right), \mathrm{DC}, \mathrm{CC}$; Baba Mt., Kopanki chalet - Jorgov Kamen place, $1600-1700 \mathrm{~m}\left(41.021^{\circ} \mathrm{N}\right.$, $\left.21.223^{\circ} \mathrm{E}\right)$; Crveni Steni place, $1800 \mathrm{~m}\left(41.0068^{\circ} \mathrm{N}, 21.2088^{\circ} \mathrm{E}\right)$; Lovechka Koliba Place, $1850-2190 \mathrm{~m}\left(41.0079^{\circ} \mathrm{N}, 21.168^{\circ} \mathrm{E} \&\right.$ $\left.41.0036^{\circ} \mathrm{N}, 21.1683^{\circ} \mathrm{E} \& 40.9952^{\circ} \mathrm{N}, 21.1706^{\circ} \mathrm{E}\right)$; Rupa place, $2100 \mathrm{~m}\left(40.8775^{\circ} \mathrm{N}, 21.2376^{\circ} \mathrm{E}\right)$; Golemo Ezero - Muza Peak, $2000-2250 \mathrm{~m}\left(40.9468^{\circ} \mathrm{N}, 21.2377^{\circ} \mathrm{E} \& 40.9556^{\circ} \mathrm{N}, 21.214^{\circ} \mathrm{E}\right)$ (all data for Baba Mt. by Micevski et al., 2003 as P. fieberi); Kozjak Mt.: Krusha place - the ridge, $1700 \mathrm{~m}\left(41.1072^{\circ} \mathrm{N}\right.$, $\left.21.9044^{\circ} \mathrm{E}\right)($ Chobanov, 2002 as P. fieberi); Kozhuf Mt.: Dve Ushi peak, 1700-1800 m (Grebenshchikov, 1950 as P. fieberi; Mikšić, 1965 ["Dvousje kod Gevgelije"] as P. illyricus macedonicus) $\left(41.2213^{\circ} \mathrm{N}, 22.2847^{\circ} \mathrm{E}\right), \mathrm{DC}, \mathrm{CC}$; Kechi Kaja peak, 1750 $1787 \mathrm{~m}\left(41.1968^{\circ} \mathrm{N}, 22.2474^{\circ} \mathrm{E}\right), \mathrm{DC}, \mathrm{CC}$; Mihajlovo - Dudica peak, $1600-2100 \mathrm{~m}\left(41.1698^{\circ} \mathrm{N}, 22.256^{\circ} \mathrm{E}\right), \mathrm{DC}, \mathrm{CC}$; Dzhibarica - Zelen Beg ridges, $1650-2000 \mathrm{~m}\left(41.1891^{\circ} \mathrm{N}, 22.2146^{\circ} \mathrm{E} \&\right.$ $\left.41.1656^{\circ} \mathrm{N}, 22.2118^{\circ} \mathrm{E}\right), \mathrm{DC}, \mathrm{CC}$; Mala Rupa ridge, $1600-2000$ $\mathrm{m}\left(41.1651^{\circ} \mathrm{N}, 22.2491^{\circ} \mathrm{E}\right), \mathrm{DC}, \mathrm{CC}$; Porta Peak, 2000-2100 m $\left(41.1499^{\circ} \mathrm{N}, 22.1638^{\circ} \mathrm{E} \& 41.1574^{\circ} \mathrm{N}, 22.1692^{\circ} \mathrm{E}\right), \mathrm{DC}, \mathrm{CC}$; Zelen Beg-Dudica peaks, $1600-2100 \mathrm{~m}\left(41.1276^{\circ} \mathrm{N}, 22.144^{\circ} \mathrm{E} \&\right.$ $\left.41.1391^{\circ} \mathrm{N}, 22.15^{\circ} \mathrm{E}\right), \mathrm{DC}, \mathrm{CC}$.

Greece: Florina: Kaimakchalan Mt. $\left(40.93111^{\circ} \mathrm{N}, 21.7892^{\circ} \mathrm{E}\right)$ (Werner, 1933 as $P$. fieberi macedonicus); Bela Voda Mt. $\left(40.80972^{\circ} \mathrm{N}, 21.21^{\circ} \mathrm{E}\right)$ (Willemse, 1977 as P. fieberi macedonicus); Vernon Mt., $4 \mathrm{~km} \mathrm{E}$ of Pisodheri $\left(40.766^{\circ} \mathrm{N}, 21.2167^{\circ} \mathrm{E}\right)$ (Willemse, 1977 as P. fieberi macedonicus); Vernon Mt. $\left(40.751^{\circ} \mathrm{N}, 21.257^{\circ} \mathrm{E}\right)$ (Heller, 1988 as P. fieberi macedonicus); Imathia: Vermion Mt., $\mathrm{W}$ of Naoussa, above refuge Tria Pigadhia $\left(40.629^{\circ} \mathrm{N}, 21.985^{\circ} \mathrm{E}\right.$ ) (Willemse, 1977 as $P$. fieberi macedonicus); Kozani: Pieria Mt., above Katafiyio $\left(40.2552^{\circ} \mathrm{N}\right.$, $22.1626^{\circ} \mathrm{E}$ ) (Willemse, 1977 as $P$. fieberi macedonicus); Pieria Mt., $1680 \mathrm{~m}\left(40.25^{\circ} \mathrm{N}, 22.154^{\circ} \mathrm{E}\right)$ (Heller, 1988 as P. fieberi macedonicus); Ioannina: Smolikas Mt., above A. Paraskevi $\left(40.1^{\circ} \mathrm{N}\right.$, $20.917^{\circ} \mathrm{E}$ ) (Willemse, 1977 as P. fieberi macedonicus); Evritania, Timfristos Mt., above Karpenision $\left(8.9435^{\circ} \mathrm{N}, 21.8015^{\circ} \mathrm{E}\right)$ (Willemse, 1977 as P. fieberi macedonicus); Peristeri ("Peristori, Metsovan") $\left(39.81667^{\circ} \mathrm{N}, 21.1333^{\circ} \mathrm{E}\right)$ (Harz, 1976 as P. fieberi macedonicus); Lake near Metsovon $\left(39.8145^{\circ} \mathrm{N}, 21.142^{\circ} \mathrm{E}\right), \mathrm{K} . \mathrm{-G}$ Heller \& M. Heller, CH; $3 \mathrm{~km} \mathrm{~N}$ of Metsovon [Metsovo], $1400 \mathrm{~m}$ $\left(39.79^{\circ} \mathrm{N}, 21.162^{\circ} \mathrm{E}\right)$ (Willemse, 1977 as P. fieberi macedonicus); Dokimi Mt., $10 \mathrm{~km} \mathrm{SE}$ of Metsovon, Ski Centre Anilio, 1630 $1650 \mathrm{~m}\left(39.7465^{\circ} \mathrm{N}, 21.225^{\circ} \mathrm{E}\right)$, K.-G. Heller \& M. Heller, CH; Phthiotis: Oiti Mt., above Ipati (Willemse, 1977 as P. fieberi macedonicus); Oiti Mt., "Hochfläche zw. Pira und Pavliani (HeraklesScheiterhaufen)", $1000 \mathrm{~m}\left(38.76667^{\circ} \mathrm{N}, 22.3^{\circ} \mathrm{E}\right)$ (Heller, 1988 as P. fieberi macedonicus); $6-10 \mathrm{~km} \mathrm{NW}$ of Pavliani $\left(38.7639^{\circ} \mathrm{N}\right.$, $22.305^{\circ} \mathrm{E}$ ) (Willemse, 1977 as $P$. fieberi macedonicus). 


\section{Incertae sedis}

\section{Psorodonotus illyricus / macedonicus?}

Montenegro: Bilo [unclear locality position] (Grebenshchikov, 1950 as P. fieberi); Bijela Planina [unclear locality position] (Mikšić, 1965 as P. illyricus illyricus/macedonicus transitional form); Đuranica gora [unclear locality position] (Mikšić, 1965 as P. illyricus illyricus/macedonicus transitional form).

\section{Psorodonotus fieberi / macedonicus?}

?Serbia: "Radoč (S Serbia)" [uclear locality position] (Ebner, 1923 as P.f. fieberi (female similar to P.f. illyricus);

\section{References cited in Appendix 2 and additional to the} references in the text

Bey-Bienko G.YA. \& Peshev G. 1960: A study of the fauna of orthopterans (Orthoptera) in Bulgaria. - Bull. Inst. Zool. Mus. Acad. Sci. Bulg. (Sofia) 9: 3-51 [in Russian, English abstr.].

Buresch I. \& Peschev G. 1958: Artenbestand und Verbreitung der Geradflügler (Orthopteroidea) in Bulgarien (unter Berücksichtigung der schädlichen Heuschrecken). III. Tettigonioidea. - Bull. Inst. Zool. Mus. Acad. Sci. Bulg. (Sofia) 7: 3-90 [in Bulgarian, German abstr.].

Chobanov D.P. 2002: Results of the orthopterological investigations from Ograzden and Kozjak Mts., Republic of Macedonia. - Bull. Biol. Stud. Res. Soc. (Skopje) 2: 111-117.

Chobanov D.P. 2012: Dermaptera, Blattodea, Mantodea and Orthoptera of the Western Rhodopes (Bulgaria and Greece). In Beron P. (ed.): Biodiversity of Bulgaria 4. Biodiversity of Western Rhodopes (Bulgaria and Greece) II. Pensoft and Natn. Mus. Nat. Hist., Sofia, pp. 163-211 [dated 2011].

Chobanov D.P. \& MinaJlova B. 2010: Orthoptera and Mantodea (Insecta) in the collection of the Macedonian Museum of Natural History (Skopje) with an annotated check-list of the groups in Macedonia. - Articulata 25(1): 73-107.

Chobanov D.P., Grzywacz B., Iorgu I., Çiplak B., Ilieva M. \& WarChalowsKa-Śliwa E. 2013: Review of the Balkan Isophya (Orthoptera: Phaneropteridae) with particular emphasis on the Isophya modesta group and remarks on the systematics of the genus based on morphological and acoustic data. - Zootaxa 3658: $1-81$.

Dimovski A. 1968: Die Biogeographische und Oekologische Charakteristik des Kessels von Skopje. - Annu. Fac. Sci. Univ. Skopje 20[1967]: 1-70 [in Macedonian, German abstr.].

DRENOWSKI A.K. 1927: [A note for mountainous Orthoptera from Osogova Mountain]. — Mitt. Bulg. Entomol. Ges. Sofia 4: 17 [in Bulgarian].

DrenowsKi A.K. 1929: Première contribution à l'étude des sauterelles (Orthoptera) en Bulgarie. - Spis. Bulg. Akad. Nauk. (Prir-Mat.) 41: 167-176 [in Bulgarian, French abstr.].

FreY-Gessner E. 1893: Orthoptern [sic] gesammelt in Bulgarien von Herrn Prof. Dr. A. Forel. - Mitt. Schweiz. Entomol. Ges. Geneve 8: 397-403.

Harz K. 1976: Orthopterologische Beiträge XV. - NachrBl. Bayer. Entomol. 25(3): 54-58.

KarAman M.S. 1975: Etude taxonomique, zoogéographique et écologique des Orthopteroides de la plaine de Skoplje. Zajednica Naućnih Ustanova Sap Kosova Knjiga 35, Priština, 156 pp. [in Serbo-Croatian, French and Albanian abstr].

Micevski B., Chobanov D. \& Pop-Stojanov D. 2003: [The Fauna of Orthoptera of the National Park Pelister]. BSPSM 4, Skopje, 99 pp. [in Macedonian].

NADIG A. 1987: Saltatoria (Insecta) der Süd- und Südostabdachung der Alpen zwischen der Provence im W, dem pannonischen Raum im NE und Istrien im SE (mit Verzeichnissen der Fundorte und Tiere meiner Sammlung) I. Teil: Laubheuschrekken (Tettigoniidae). — Rev. Suisse Zool. 94: 257-356.

Nedelkov N. 1908: [Second contribution to the entomological fauna of Bulgaria]. - Period. Spis. Bulg. Knizh. Druzh. Sofia 19: 411-436 [in Bulgarian].
Peshev G.P. 1962: Composition et répartition écologique des Orthoptères de la montagne Belassitza. - Bull. Inst. Zool. Mus. Acad. Sci. Bulg. (Sofia) 12: 59-107 [in Bulgarian, French abstr.].

[Peshev 1970] Peschev G. 1970: Die Orthopteren im westlichen Balkangebirge. - Bull. Inst. Zool. Mus. Acad. Sci. Bulg. (Sofia) 31: 173-202 [in Bulgarian, German abstr.].

[Peshev 1974a] Péchev G. 1974: Orthoptères du Rhodope. Répartition et groupement écologiques. - Bull. Inst. Zool. Mus. Acad. Sci. Bulg. (Sofia) 40: 99-131 [in Bulgarian, French abstr.].

[Peshev 1974b] Pešev G. 1974: Les Orthoptères de la Stara Planina. - Bull. Inst. Zool. Mus. Acad. Sci. Bulg. (Sofia) 41: 65-92 [in Bulgarian, French abstr.].

[Peshev 1975] Péchev G. 1975: La faune orthoptérologique (Orthoptera) des Rhodopes II. Composition spécifique, distribution et origine. In: La Faune des Rhodopes. Materiaux. Bulgarian Academia of Sciences, Sofia, pp. 93-120 [in Bulgarian, French abstr.].

Peshev G.P. 1990: [Biogeographic importance of disjunct distribution of the mountainous orthorterans (Orthoptera) in Bulgaria]. - Acta Zool. Bulg. 39: 16-24 [in Bulgarian].

Peshev G. \& Andreeva E. 1986: [Orthoptera in Southwest Bulgaria. I. Fauna]. In: Fauna of Southwestern Bulgaria 1. Bulgarian Academy of Sciences, Sofia, pp. 82-117 [in Bulgarian].

Pungur G. 1899: Die Orthopteren Ungarns. - Rovartani Lapok 7: 9-11 [in Hungarian].

Us F. 1938: Doprinos poznavanju ortopterske faune u Jugoslaviji [A contribution to the knowledge of the orthopteran fauna of Yugoslavia]. - Prirod. Razpr. SAZU (Ljubljana) 3: 239-252 [in Serbo-Croatian].

Us F. 1992: Fauna of Orthopteroidea in Slovenia. Slovenska Akad. Znanosti Umetnosti Razred Naravoslovne Vede Dela 32, Academia Scientiarum et Artium Slovenica, Ljubljana, 314 pp.

WERNER F. 1933: Beiträge zur Kenntnis der Tierwelt von Ost-Tirol. II Teil. Insekten, Spinnen- und Krebstiere. - Veroeff. Mus. Ferdinand. Innsbruck 13: 357-388.

WILLEMSE F. 1977: Interesting distribution records of Orthoptera from Greek mainland and some neighbouring islands. - Entomol. Ber. (Amsterdam) 37: 52-59.

APPENDIX 3. GenBank Accession numbers of material used in this study.

\begin{tabular}{lcc}
\hline Haplotype (see Fig. 9) & Haplotype no. & GenBank accession no. \\
\hline P. venosus & $1536 \mathrm{cArdCv}$ & KP639712 \\
P. specularis & 1020-1ArdCs & KP639730 \\
P. cancasicus 1 & $1457 \mathrm{ErmYc}$ & KP639713 \\
P. cancasicus 2 & $1458 \mathrm{cErmYc}$ & KP639714 \\
P. macedonicus 1 & $1859 \mathrm{cMacKfb}$ & KP639725 \\
P. macedonicus 2 & $1886 \mathrm{cMacKfb}$ & KP639728 \\
P. macedonicus 3 & $1869 \mathrm{cMacBfb}$ & KP639726 \\
P. macedonicus 4 & $1873 \mathrm{cMacBfb}$ & KP639727 \\
P. macedonicus 5 & $1963 \mathrm{cMacJfb}$ & KP639729 \\
P. fieberi 1 & $1240 \mathrm{cBulBfb}$ & KP639715 \\
P. fieberi 2 & $1856 \mathrm{cBulBfb}$ & KP639720 \\
P. fieberi 3 & $1637 \mathrm{cBulSfb}$ & KP639716 \\
P. fieberi 4 & $1644 \mathrm{cBulVzfb}$ & KP639717 \\
P. fieberi 5 & $1645 \mathrm{cBulSfb}$ & KP639718 \\
P. fieberi 6 & $1646 \mathrm{cBulSfb}$ & KP639719 \\
P. illyricus 1 & $2177 \mathrm{cbHirPily}$ & KP639721 \\
P. illyricus 2 & $2178 \mathrm{cbHirPily}$ & KP639722 \\
P. illyricus 3 & $2162 \mathrm{cbHirVily}$ & KP639723 \\
P. illyricus 4 & $2164 \mathrm{cHirVily}$ & KP639724 \\
\hline
\end{tabular}

